\author{
Federal Reserve Bank of Dallas \\ Globalization and Monetary Policy Institute \\ Working Paper No. 184 \\ http:/ / www.dallasfed.org/ assets/ documents/ institute/ wpapers/ 2014/ 0184.pdf
}

\title{
Bank Crises and Sovereign Defaults in Emerging Markets: Exploring the Links*
}

\author{
Irina Balteanu \\ Bank of Spain \\ Aitor Erce \\ European Stability Mechanism and Bank of Spain
}

June 2014

\begin{abstract}
This paper provides a set of stylized facts on the mechanisms through which banking and sovereign distress feed into each other, using a large sample of emerging economies over three decades. We first define "twin crises" as events where banking crises and sovereign defaults combine, and further distinguish between those banking crises that end up in sovereign debt crises, and vice-versa. We then assess what differentiates "single" episodes from "twin" ones. Using an event analysis methodology, we study the behavior around crises of variables describing the balance sheet interconnection between the banking and public sectors, the characteristics of the banking sector, the state of public finances, and the macroeconomic context. We find that there are systematic differences between "single" and "twin" crises across all these dimensions. Additionally, we find that "twin" crises are heterogeneous events: taking into account the proper time sequence of crises that compose "twin" episodes is important for understanding their drivers, transmission channels and economic consequences. Our results shed light on the mechanisms surrounding feedback loops of sovereign and banking stress.
\end{abstract}

JEL codes: E44, F34, G 01, H63

\footnotetext{
* Irina Balteanu, Bank of Spain, Alcala 44, 28014, Madrid, Spain. 34-913387041. irina.balteanu@bde.es. Aitor Erce, Economic \& Market Analysis, European Stability Mechanism, 6a, Circuit de la Foire Internationale, L-1347, Luxembourg City, Luxembourg. 352-621345617. a.erce@esm.europa.eu. We thank Enrique Alberola, Rebeca Anguren, Fernando Broner, Mathieu Bussière, Juan Fran Jimeno, Gabriel Perez-Quirós, Enisse Kharroubi, Richard Portes and seminar participants at 2014 Emerging Market Finance Workshop (Cass Business School), Bank of Spain, 2012 European Summer Symposium in International Macroeconomics, Bank for international Settlements, 2012 Workshop for the Sixth High-Level Seminar of the Eurosystem and Latin American Central Banks, Tenth Emerging Markets Workshop and CEMLA Meetings for their comments and suggestions. We also thank Laura Fernandez, Silvia Gutierrez, Monica Gomez and Beatriz Urquizu for their excellent research assistance. The views in this paper are those of the authors and do not necessarily reflect the views of the Bank of Spain, the European Stability Mechanism, the Eurosystem, the Federal Reserve Bank of Dallas or the Federal Reserve System.
} 


\section{Introduction}

Due to the expansion of balance sheets, falling capital ratios and product innovation, risks in the banking systems across the world have risen steadily in the last decades, leading to an increase in the frequency and scale of public interventions after financial crises (Alessandri and Haldane, 2009). In turn, these interventions have strained governments and, at times, threatened the sustainability of public debt (Reinhart and Rogoff, 2011). Still, there is evidence that the transmission of distress has often gone in the opposite direction, with situations of acute fiscal stress triggering systemic banking crises (Caprio and Honohan, 2008).

The two-way interaction between the banking and public sectors has attracted increased attention lately, as the recent crisis has engulfed a number of advanced economies into a perverse feedback loop of fiscal and financial distress. On the one hand, a number of countries faced severe banking crises, which triggered fiscal troubles due to the magnitude of bank rescue operations. Arguably, this is what happened to Iceland and Ireland, where the materialization of contingent claims in the form of deposit guarantees brought havoc to the sovereign's balance sheet ${ }^{4}$. On the other hand, pro-cyclical fiscal policy and a lack of competitiveness, among other factors, led to a sovereign debt crisis in Greece in early 2010. As foreign investors withdrew, banks became major holders of public debt. Successive sovereign downgrades, ending in a private sector involvement operation, contributed to the collapse of the Greek banking sector.

While these recent developments have sparked a growing interest in the nature of feedback loops between the sovereign and the banking sector in the euro area ${ }^{5}$, intertwined fiscal and financial crises are nothing new, as emerging economies know too well. Ecuador (in the mid-nineties) and Dominican Republic (in the early 2000s) accumulated so much debt trying to sort out a sequence of bank troubles that were forced to restructure their sovereign debt obligations. In turn, during the Argentinean (2001) and Russian (1998) crises, governments relied heavily on domestic banks as a source of financing. The eventual sovereign defaults imposed large losses on the heavily exposed banks, ultimately triggering banking crises ${ }^{6}$.

Against this background, it is surprising that the large literature looking at how different types of crises occur and combine (the so-called "twin crises" literature) has

\footnotetext{
${ }^{4}$ In Iceland, bank failures directly increased net public debt by 13\% of GDP (Carey, 2009).

5 See Mody and Sandri (2011), Acharya et al. (2013), Alter and Beyer (2013) or Moody's (2014).

6 Diaz-Cassou et al. (2008) provides a detailed accounts of these episodes.
} 
only recently begun to examine the links between fiscal and financial distress. Moreover, most papers focus on either one or the other direction of transmission, and only a few papers address the two-way nature of the relationship. Concerning emerging economies, there are two notable exceptions: Panizza and Borenzstein (2008) and Reinhart and Rogoff (2011). Panizza and Borenzstein (2008) find that the probability of a banking crisis conditional on a default is much higher than the unconditional probability of a banking crisis, while the probability of a default conditional on a banking crisis is just slightly higher than the unconditional one. Reinhart and Rogoff (2011) analyze the cycles underlying serial debt and banking crises using long time-series on public and external debt, and obtain exactly the opposite result: it is banking crises that turn out to be significant predictors of sovereign debt crises, and not the other way around ${ }^{7}$. One drawback of these studies is that, while they nicely discuss the channels of transmission between sovereign and bank distress, they do not study these channels formally.

A similar criticism applies to the growing literature focusing on the existence of feedback loops between sovereign and financial risks in the euro-area. These recent contributions study the two-way relationship between fiscal and financial tensions by modelling the common dynamics of banks' and sovereigns' Credit Default Swaps ${ }^{8}$. While the various time series methodologies used in these studies present interesting ways to measure the extent to which sovereign stress drives bank stress and vice-versa, they do not incorporate any macroeconomic and financial variables and, thus, fail to explain the potential drivers and transmitters of this feedback relation

This paper aims to address this gap by studying the behavior of a larger set of macro-financial variables through which the transmission between fiscal and financial stress may materialize. We are particularly interested in variables describing the balance sheet interconnection between the banking and public sectors, as well as the characteristics of the banking sector, the state of public finances, and the overall economy.

New to the literature, we isolate the following types of events: (i) "single" banking crises i.e. banking crises that are not followed by sovereign defaults; (ii) "single"

\footnotetext{
7 These diverging results might be partly explained by the use of different samples and econometric strategies. In a narrower sample, Erce (2012) documents both types of feedback episodes.

${ }^{8}$ Moody's (2014) study the dynamic relation between sovereign and bank CDS spreads by means of a Markov switching VAR methodology. Similarly, Alter and Beyer (2013), following Diebold and Yilmaz (2009), show a growing interdependence between fiscal and financial risks in the euro area. Broto and Perez-Quirós (2013) use a dynamic factor model to decompose the sovereign CDS spreads into a common factor, a factor driven by peripheral countries and an idiosyncratic component. In turn, Heinz and Sun (2014) use a panel GLS error correction framework to analyze the drivers of sovereign CDS spreads in the euro-area and emerging European countries.
} 
sovereign debt crises i.e. sovereign defaults not followed by banking crises; (iii) "twin bank-debt" crises, which start with a banking crisis, followed by a sovereign one; and (iv) "twin debt-bank" crises, where a sovereign crisis is followed by a banking one. We use a large sample of emerging countries over three decades and an event analysis methodology as in Broner et al. (2013) and Gourinchas and Obstfeld (2012) to study the behavior of our variables during a seven-year time window around each type of crises. We are interested in what differentiates "single" banking crises from those that bring down the sovereign and, similarly, what differentiates "single" sovereign defaults from those that eventually lead to banking crises.

Our contribution is two-fold. First, we find that there are systematic differences between "single" crises and "twin" ones. By distinguishing between "single" and "twin" events, we find that a number of empirical facts usually associated with either "banking" or "debt" crises in general are to be found in "twin" events only, and not in "single" episodes. Second, we show that considering the sequence of crisis within "twin" events, that is, taking into account whether the trigger of a "twin" crisis is a debt crisis or a banking one, is important for understanding their transmission channels and the economic consequences of policies deployed to solve them.

Regarding the differences between "single" banking and "twin bank-debt" events, our results can be summarized as follows. The interplay between banks' and both Central Bank's and government's balance sheets differs significantly in terms of levels and dynamics, pointing to a combination of differences in the size and timing of initial shocks, banking sector characteristics, and policy strategies used to deal with banking sector problems. On average, banking systems are significantly larger and deeper around banking crises that are part of "twin" events. In "single" episodes, banks start sizing down ahead of the crisis and continue to do so as the crisis unfolds. In contrast, in "twin" episodes, not only does asset downsizing start late into the banking crisis, but also the process is more gradual. This might indicate that the policy response is to try to keep the banking sector afloat, postponing deleveraging until the crisis engulfs the public sector as well.

While the two events occur against similar initial debt and budget positions, diverging patterns of public finances emerge once banking crises are underway. Banking crises that are part of "twin" bank-debt events are associated with a sharper increase in budget deficit, on the account of a shoot-up in public spending, as well as with a larger accumulation of public debt, which suggests that they put more strains on government finances than "single" banking events. Finally, banking crises that are part of "twin" episodes have a more damaging and persistent effect 
on the economy in terms of growth and inflation. These events are also associated with a larger loss in foreign investors' confidence, as reflected in a sudden stop of portfolio inflows and a sharp change in the composition of foreign debt towards short-term liabilities.

Regarding the differences between "single" debt and "twin debt-bank" crises, we find that, ahead of the latter, the average banking sector is more exposed to the government and the pace of increase in its public debt holdings is faster. The amount of liquidity support provided by the central bank around the two episodes is significantly larger than in non-crisis times, suggesting that banking sector tensions accompany both events, including "single" ones. Nevertheless, while the liquidity support is flat throughout "single" crises, it increases dramatically during "twin" ones. These large differences in the levels and dynamics of central bank support and banks' exposure to the sovereign could indicate that, on the one hand, "twin" defaults are more damaging to banks' balance sheets, and, on the other hand, they leave the sovereign with less margin to support the banking sector.

While the state of public finances is roughly similar ahead of the two events, public expenditure is cut more drastically (and public debt drops faster) in the aftermath of "twin" defaults. This could point to either a lack of fiscal space, or the adoption of a more austere stabilization package, both of which may negatively affect the banking sector and the economy in the short run. Defaults associated with "twin" events have a larger immediate negative impact on growth, while the recovery in the aftermath is slower. These growth dynamics are accompanied by inflation rates that fall more markedly during "twin" events than during "single" ones. Finally, "twin" defaults are accompanied by sharp drops in portfolio capital inflows and a shift in the composition of foreign borrowing towards shorter maturities, reflecting the large loss of credibility suffered by the sovereign.

Apart from the systematic differences between "single" and "twin" crises, our analysis also shows that "twin" crises themselves are far from being homogenous events. By taking into account the different sequence of crises during "twin" episodes, we are able to uncover contrasting dynamics, such as those of budget deficits, budget expense, inflation and portfolio capital flows, which would have otherwise gone unnoticed. We thus provide a more refined characterization of the environment around "twin" crises.

Our results add to a literature aimed at uncovering stylized facts associated with financial and economic crises. We believe that these results, by providing a detailed 
understanding of the economic dynamics around different crisis episodes, can help in building better early warning indicators, as well as in designing theoretical models where these issues can be studied more formally.

The event study presented in this paper is useful in terms of uncovering important stylized facts, particularly in revealing nonlinear relationships. Still, this methodology is not suitable for examining causality and, moreover, cannot discriminate among the various mechanisms at work behind the dynamics of individual variables. Addressing these issues requires a structural model, which is the next step on our research agenda.

The rest of the paper is organized as follows. The following section provides a discussion of the main feedback channels between bank and sovereign distress, as identified so far in the literature. Section 3 introduces the definitions of crises, as well as the data and methodology, while section 4 discusses the main results of this paper. Section 5 concludes.

\section{How does distress transmit? An overview of the literature}

In order to guide our choice of variables, we briefly discuss the main channels through which financial tensions may lead to sovereign stress, and vice-versa. These channels include direct balance sheet interconnections, through public rescue operations and banks' holdings of public debt, as well as other indirect ways through which underlying vulnerabilities in either the banking or public sector may materialize into twin crises.

As argued above, few papers have focused on the two directions of transmission between fiscal and financial stress in emerging countries. More evidence is recently being provided on the feedback loops between banks and sovereigns in the euroarea. According to Moody's (2014), the euro-area did not suffer one financial crisis, but a variety of crises, each of them with its own specificities. Accordingly, only Ireland witnessed a spill over of financial stress into sovereign stress. Instead, the opposite occurred in Greece and Italy, where sovereign stress lead to financial crises. For the rest of the countries analysed, the article finds evidence of a two-way relationship, with stress feeding back in both directions, as also documented by Alter and Beyer (2013). 


\subsection{Channels through which banking crises may affect the sovereign}

Banking crises may put strains on governments through both direct and indirect channels. The former refers to the fiscal costs that the sovereign incurs when attempting to bail out the banking sector, or when explicit guarantees and contingent liabilities materialize. The latter goes through the impact of banking crises, and of policies deployed to address them, on the economy and market sentiment.

In their study on the link between banking and debt crises across history, Reinhart and Rogoff (2011) put forward four stylized facts. First, banking crises, both homegrown and imported, usually accompany or lead (predict) sovereign debt crises. Second, external (private and public) debt surges ahead of banking crises. Third, public borrowing increases sharply ahead of sovereign debt crises, and, moreover, it turns out that the government has additional "hidden debts" (domestic public debt and contingent private debt) ${ }^{9}$. Fourth, the composition of debt shifts towards the short-term before both debt and banking crises.

According to Candelon and Palm (2010), there are four main channels of transmission from banking crises to the sovereign. First, rescue operations may impair the sustainability of public finances ${ }^{10}$. These operations can include bailout money, liquidity provisioning by the central bank, public recapitalization and the execution or materialization of public guarantees. ${ }^{11}$ Second, if contingent liabilities materialize, fiscal costs are likely to be substantial. Next, the risk premium increases even if guarantees are not exercised, raising borrowing costs for both the sovereign and the private sector ("sovereign ceiling") ${ }^{12}$. Last, the economic downturn typically accompanying financial crises increases the deficit and drives up public debt.

In the same vein, Reinhart and Rogoff (2009) provide evidence of a strong negative impact of financial turmoil on asset prices, employment and output. The deterioration of the fiscal position after a banking crisis is likely to occur due to a combination of lower revenues and higher expenditures (assistance to troubled

\footnotetext{
${ }^{9}$ In fact, keeping domestic debt in the picture explains why governments default at low external debt levels, or resort to inflation to reduce the debt burden (Reinhart and Reinhart, 2009).

10 Rosas (2006) studies the drivers of government intervention after banking crises. He finds that authorities are more likely to bailout failing institutions in open and rich economies or if financial turmoil was caused by regulatory issues. On the other hand, electoral constraints and central bank independence seem to favor bank closure.

11 The direct fiscal costs of banking crises are well documented - see Feenstra and Taylor (2012), Reinhart and Rogoff (2011) or Arellano and Kocherlakota (2012).

12 Laeven and Valencia (2012) show that blanket guarantees increase the fiscal costs of banking crises, but this can also be due to the fact that they are set in place during big crises.
} 
banks and outlays associated with the economic downturn). Indeed, the paper argues that that the critical factor behind fiscal distress is not the cost of bank rescue operations, but rather the collapse in tax revenues in the wake of the deep contractions associated with financial crises. These effects are specific to each episode, but estimated fiscal costs of the median systemic banking crisis stand at $15.5 \%$ of GDP, while public debt increases by around 30\% of GDP during these episodes. (Honohan, 2008). Moreover, according to Baldacci and Gupta (2009), using fiscal policy to solve banking crises may lead, even in a favorable external environment, to sharp rises in debt and deficit. ${ }^{13}$ Distress can transmit even if exante levels of debt are relatively low. Over half of the default episodes surveyed by Reinhart and Reinhart (2009) took place with debt levels below 60\% of GDP. As argued in Goldstein (2003), a low debt to GDP level is not indicative of sustainable debt positions because it fails to take into account contingent liabilities.

Laeven and Valencia (2011) focus on the impact of financial sector interventions on the capacity of the financial system to provide credit. Their results show that firms dependent on external financing benefit significantly from bank recapitalization operations. Similarly, Kollmann et al. (2012) consider the recent bank rescue operations and find that these improve macroeconomic performance. Still, while they show that bank rescues lead to increased investment, they find that sovereign debt purchases by domestic banks lead to a crowding out of private investment, in line with the evidence in Broner et al. (2014) and Popov and Van Horen (2013). Gray and Jobst (2013) present a less benign exercise, showing the potentially high impact on fiscal risk associated with the existence of contingent liabilities ${ }^{14}$.

Additionally, banking crises may ignite a currency crash that makes public authorities unable to repay foreign currency debt (Reinhart and Rogoff, 2011, De Paoli et al., 2009). Indeed, according to Buiter (2008), the risk of a triple bankingcurrency-sovereign crisis is always there for small countries with a large and internationally exposed banking sector, a currency that is not a global reserve currency and limited fiscal capacity. ${ }^{15}$ This is more likely to happen if the central bank uses reserves to finance bailouts, or the government uses monetization to overcome the crisis.

Finally, banking crises could lead to a drop in external financing, via their impact on market sentiment. While Reinhart and Rogoff (2008a) find that banking crises are

\footnotetext{
${ }^{13}$ Their paper argues that the composition of fiscal stimulus determines the length of financial crises. Fiscal expansions do not improve the growth outlook by themselves and lead to higher interest rates on long-term government debt. The authors identify a trade-off between boosting aggregate demand (short-run) and productivity growth (long-run).

${ }^{14}$ See also Gray et al. (2013).

${ }^{15} \mathrm{http} / / /$ blogs.ft.com/maverecon/2008/11/how-likely-is-a-sterling-crisis-or-is-london-really-reykjavik-on-thames/
} 
often preceded by large capital inflows ${ }^{16}$, Cavallo and Izquierdo (2009) provide evidence showing that, after financial crises in emerging markets, capital flows may collapse for months or years, potentially triggering a solvency crisis. Focusing on the recent crisis in advanced economies, Van Rixtel and Gasperini (2013) show that banks' borrowing constraints in foreign currency affect the creditworthiness of the sovereigns. All these can be worsened by too much foreign debt and too much short-term debt. As argued by Obstfeld (2011) when discussing the role of international liquidity in the recent debt crisis, "...gross liabilities, especially those short-term, are what matter".

\subsection{Channels through which sovereign distress may affect banks}

When considering the transmission channels of a fiscal crisis to the broader economy, a number of these can be traced through the domestic financial system. Whenever assets need to be written off, rescheduled, or simply marked-to-market, banks are usually the first in line to take a hit. Noyer (2010), among others, argue that banks' holdings of defaulted government bonds might lead to large capital losses and thus threaten the solvency of different elements of the banking sector. In addition, authorities often react to debt problems by coercing domestic creditors to hold government bonds (frequently in non-market terms), aggravating the situation in the event of a default (Díaz- Cassou et al., 2008). For instance, prior to the 2001 crisis, half of Argentina's bank assets were public sector liabilities. In Russia, the severe sovereign debt crisis had a much weaker effect on overall wealth and activity than what would have been typically expected because financial intermediation was so low ${ }^{17}$.

Reinhart and Rogoff (2008b) show that defaults often go hand in hand with inflation, currency devaluations and crashes, and banking crises $^{18}$. IMF (2002) provides a comprehensive overview of the effects of four sovereign restructurings (Ecuador, Pakistan, Russia and Ukraine) on the domestic banking sector. Apart from the direct losses associated with banks' holdings of government securities, the paper also documents an increase in the interest rates on liabilities (due to the higher risk not being matched by increased returns on assets - on the contrary, in this context government securities usually offer non-market rates), as well as an increase in the

\footnotetext{
${ }^{16}$ Moreover, they find that periods of high international capital mobility gave rise to banking crises in the past. The probability of a banking crisis conditional on a capital flow bonanza is higher than the unconditional probability in $61 \%$ of the countries they cover (for the period 1960-2007).

17 Erce (2012) suggests that the degree of bank intermediation strongly affects a debt restructuring's ripple effect on the economy. The disruptions caused by Ecuador's bigger and more developed banking system were comparatively larger. In contrast, one could expect a smaller effect in economies where firms rely more on non-bank sources of financing.

18 De Paoli et al. (2009) find that two thirds of sovereign defaults overlap with banking crises, and almost half with both banking and currency crises.
} 
rate of nonperforming loans (as higher financing costs lead to corporate bankruptcies).

A few theoretical papers have highlighted the channels through which sovereign distress may translate into financial distress. Acharya et al. (2014) present a model in which, if the sovereign becomes overburdened, the value of any public guarantees it may provide falls, aggravating the feedback loop between the government and the financial sector. Using data on banks' sovereign debt holdings, they document the high exposure of these institutions to their own sovereign, which, according to their theory, should be a main channel through which stress backfeeds ${ }^{19}$. Similarly, Brutti (2009) focuses on the role of financial institutions as major holders of government debt and finds that the government's incentive to repay ex-post is largely given by the risk of triggering a financial crisis. Gennaioli et al. (2014) show that sovereign defaults tend to trigger capital outflows and credit crunches. In their view strong financial institutions amplify the costs of default, disciplining the government.

In Livshits and Schoors (2009), when public debt becomes risky, the government has incentives to not adjust prudential regulation. While this keeps borrowing costs low, a government default may trigger a banking crisis ${ }^{20}$. Drechsler et al. (2013) present a similar argument regarding the current situation in the euro-area. According to them, the fact that both capital regulation and the collateral policy of the ECB give preferential treatment to the euro-area government bonds, has provided incentives to banks to load up on such bonds, setting the stage for the appearance of perverse feedback loops through increased balance sheet interconnections. In Darraq-Pires et al. (2013) the positive connection between fiscal and financial risk is due to the fact that banks invest in government securities in order to hedge against future liquidity shocks. Along these lines, Angeloni and Wolff (2012) empirically assess the impact of sovereign bond holdings on the performance of banks during the euro-area crisis, using individual bank data and sovereign bond holdings.

Beyond this direct balance sheet effect, the ensuing fiscal contraction may lead to reduced economic activity affecting banks' profits and further damaging the financial system. Moreover, the economic downturn may be reinforced by a credit crunch, as banks reduce lending due to capital losses and the increase in uncertainty that comes with a sovereign default (Panizza and Borenzstein, 2008). Popov and Van

\footnotetext{
${ }^{19}$ Among other things, the paper assesses the extent to which reduced sovereign ratings affected banks' CDS through their effect on the explicit and implicit guarantees from the public sector.

${ }_{20}$ In its case study of four debt restructuring episodes, IMF (2002) shows that banks did not hold capital against sovereign credit risk. Prudential regulation in place considered government bonds risk-free even when default expectations were not zero.
} 
Horen (2013) assess the extent to which increased holdings of distressed sovereign bonds limit banks' ability to extend loans to the private sector, thus amplifying the vicious feedback loop between banks and sovereign by limiting the growth potential of the economy. They document a stronger reallocation away from domestic lending in the euro-area periphery during the recent crisis. A similar crowding out effect is documented in Broner et al. (2014), who present a battery of stylized facts on the euro-area crisis, including an increase in sovereign bond holdings by banks and a simultaneous drop in financing to the private sector ${ }^{21}$. Moreover, corporate borrowers and banks may face a sudden stop in financing after a sovereign default, even if they are not overexposed to government bonds. Gennaioli et al. (2014) and Das et al. (2011) empirically show that sovereign defaults curtail access to foreign capital for both public and private agents.

Still, an additional pressure on banks to reduce lending might come from the fact that the increased uncertainty following a sovereign default may lead to a run on banks' deposits or a collapse of the interbank market (Panizza and Borenzstein, 2008). Also, the banking system is not able to operate normally if the government imposes deposit freezes. Finally, sovereign ratings downgrades further limit banks' access to foreign financing, leading to sudden stops or higher borrowing costs (Reinhart and Rogoff, 2011).

\section{Data and methodology}

Our initial sample contains 117 emerging and developing countries, covering three decades, from 1975 to 2007. We exclude from our analysis all banking and sovereign episodes linked to the recent global crisis.

\subsection{Definition and incidence of events}

To identify and date sovereign debt crises we rely on the information provided by Standard \& Poor's (S\&P). S\&P defines sovereign defaults as situations where: (i) the government does not meet scheduled debt service on the due date or (ii) creditors are offered either a rescheduling (bank debt) or a debt exchange (bond debt) in less favorable terms than the original issue ${ }^{22}$. With regard to banking crises, we use the

\footnotetext{
${ }^{21}$ While these papers present a more nuanced view of domestic purchases of sovereign bonds, other papers have found positive feedback effects of these purchases. For instance, according to Andritzky (2012), domestic bank purchases of sovereign bonds limit the increase in the spreads, helping stabilize sovereign's funding needs.

22 While there are situations in which defaults may either take the form of high inflation episodes or be averted through an IMF intervention, we take a stricter view and focus on explicit defaults only.
} 
so-called "systemic" events identified by Laeven and Valencia (2013a) as situations in which: (i) a country's corporate and financial sectors experience a large number of defaults; (ii) and firms and financial institutions face great difficulties repaying contracts on time. Thus, this definition excludes minor banking events, in which only isolated banks are in distress.

Given that ending dates of both sovereign and banking crises are hard to establish, we mark the first year of each crisis only. Crises of the same type that occur at less than three years of distance are considered single events. Finally, we define "twin crises" as pairs of sovereign debt and banking crises that take place at intervals of less than three years one from the other.

Accordingly, we isolate the following types of events: (i) "single" banking crises i.e. banking crises that are not followed by sovereign distress; (ii) "single" sovereign debt crises i.e. sovereign defaults that are nor followed by banking crises; (iii) "twin bankdebt" crises, that start with a banking crisis, followed by a sovereign one during the following three years; and (iv) "twin debt-bank" crises, where a sovereign crisis is followed by a banking one during the following three years.

Using these definitions we obtain 121 sovereign debt crises and 113 banking crises. Of these, 36 are twin events - that is, around 30\% of either banking or debt crises compound into twin ones. Further distinguishing twin crises according to the sequence of events, we find that 17 are twin bank-debt crises and 19 are twin debtbank. Tables 1 and 2 in Appendix 1 list these twin episodes, while Table 3 offers an overview of the crises in our sample. Single episodes account for the bulk of our crises: there are 77 single banking crises and 87 single sovereign defaults. All countries in our sample experienced at least one crisis of some kind. About half experienced only one crisis, whereas one third experienced two crises; four countries (Argentina, Bolivia, Venezuela and Nigeria) experienced four crises each. A quarter of countries went through at least one twin event.

Figure 1 in Appendix 1 further shows that most crises took place during the 1980s and the 1990s. Banking crises were rare in the 1970s, due to heavy financial regulation worldwide and then again in the 2000s, up until 2007. In turn, they were heavily bunched in the 1990s, when almost $60 \%$ of the banking crises in the sample took place. Sovereign episodes are slightly more smoothly distributed than banking crises, with a peak in 1980s, when about half of them took place. Crises were more likely to combine into twin events during the 80 s and 90 s, a feature resurfacing nowadays. About $30 \%$ of the sovereign crises and more than half of the banking crises occurring during the 1980s compounded into twin events. In the following 
decade, $40 \%$ of the sovereign defaults, but only $18 \%$ of the banking crises, were part of twin events.

For the purpose of our econometric analysis, and due to significant data gaps, we exclude from the sample all low-income countries (39, mostly African, economies), which leaves us with 78 emerging market countries (and 140 distinct crises, of which 51 single banking crises, 61 single crises, 15 twin bank-debt crises and 13 twin debt-bank crises).

\subsection{Variables: definitions and sources}

In light of the discussion in section 2 on the direct and indirect channels of transmission between banking and sovereign distress, we are particularly interested in studying the behavior around crises of four categories of variables, describing: the bank-public balance sheet interconnections; the characteristics of the banking sector; the state of public finances; and the overall economy. Table 4 in Appendix 1 lists all variables used in the analysis, together with their definitions and sources.

To uncover the balance sheet interrelations between the public and banking sectors of the economy, we use the aggregate balance sheet of domestic depository institutions, as reported in the IMF's International Financial Statistics (Table 5) ${ }^{23}$. Table 5 shows how the balance sheet interconnection between the banking system and the Central Bank can be decomposed in two parts. On the asset side of the balance sheet we find: (i) reserves (including domestic currency holdings and deposits with the Central Bank); and (ii) claims on monetary authorities, which comprise securities and claims other than reserves). On the liability side, we find the credit provided by monetary authorities to the banking system ${ }^{24}$. This last entry is likely to reflect much of the financial aid that banks get from the Central Bank during turbulent times.

In turn, the balance sheet connections between the banking system and general government are given by the following series. On the asset side, we find banks' holdings of claims on Central Government, State and Local Governments, and nonfinancial public enterprises. On the liability side, we find Central Government's

\footnotetext{
23 The balance sheet information is not based on SRF. Long time series are unavailable under this new methodology.

24 This can be seen from the perspective of the Central Bank balance sheet (Claims on Deposit Money Banks, IFS line 12e). Instead, we measure banks' liabilities to the Central Bank using their own balance sheet data, but both measures should be similar. Differences may be due to coverage issues, recording transactions at different times or errors.
} 
deposits $^{25}$. For our purposes, banking system's exposure to government is computed as the sum of bank claims on the Central, State and Local governments.

Two important indicators reflecting bank-public sector interconnections cannot be recovered from our dataset, namely recapitalization expenditures and the provision of guarantees. Unfortunately there is no comprehensive cross-country dataset on banks' recapitalization costs, which is one of the main public outlays during banking crises. Public recapitalization of troubled banks can come from the Central Bank or the Central Government, and consist of loans or buying of new shares. ${ }^{26}$ In Laeven and Valencia's (2013a) sample, bank recapitalization accounts for around half of the fiscal costs. The other half is made up of asset purchases and debt relief programs.

Data are of annual frequency. Monetary and financial variables come from the IMF's International Financial Statistics database (IFS). Fiscal variables come mainly from the Economist Intelligence Unit (EIU), which is the most complete cross-country database on government revenues and expense. However, given that this dataset starts in 1980 only, for those countries with earlier crises, and for countries with missing EIU data, we collect data from a variety of alternative sources: the IFS; Mitchell's (2007) series on "International Historical Statistics"; World Economic Outlook; and individual Article IV reports. Data on debt and debt composition come from the World Bank's World Development Indicators (WDI). Finally, our macroeconomic variables come from either WDI or IFS.

\subsection{Methodology}

Following the work of Broner et al. (2013) and Gourinchas and Obstfeld (2012), we implement an event analysis methodology, which allows us to estimate how the conditional expectation of each variable depends on the temporal distance from each type of crises, given the proximity of other crises, and relative to a "tranquil times" baseline. Consider a variable of interest $Z_{i t}$, where subscripts $i$ and $t$ refer to the country and the period respectively. Our panel specification looks as follows:

$$
Z_{i t}=\alpha_{i}+\sum_{e=\{B, D, B D, D B\}} \sum_{p=-3}^{p=3} \beta_{e p} \cdot D_{e i(t+p)}+\varepsilon_{i t}
$$

\footnotetext{
25 This comprises working balances and similar funds placed by units of the central government with deposit money banks. Capital owned by the Government is not included.

${ }^{26}$ A significant amount of this cash is accounted for in some of the balance sheet items we use in the analysis. Notice that, following a recapitalization, the balance sheet of the banking system will record an increase in assets, in the form of higher: (i) deposits at the $\mathrm{CB}$, (ii) holdings of $\mathrm{CB}$ securities, (iii) cash or (iv) holdings of central government securities. On the liability side, "loans from the Central Bank/Government" or "shares and other equities" will increase. Unfortunately there is no way to discern what part of the increase in this last line is due to public recapitalization and what reflects private recapitalization.
} 
In the equation above, $D_{\text {eiltp) }}$ denotes a dummy variable equal to 1 when country $i$ is $p$ periods away from a crisis of type $e$ in period $t$. The index $e$ denotes, respectively, debt crises $(D)$, systemic banking crises $(B)$, twin debt-bank crises $(D B)$ and twin bank-debt crises $(B D)$. The event window around crisis episodes is set to seven years - three years before and three years after the crisis. The regression allows for country fixed effects, $\alpha_{i}$ and, in some specifications, for country-specific trends. The error term $e_{i t}$ captures all the remaining variation.

Our sample is highly heterogeneous. In order to minimize the effect of heterogeneity, and that of the most extreme observations, we normalize our variables by dividing each series by country-specific standard deviations.

The coefficients $\beta_{\mathrm{ep}}$ measure the conditional effect of a crisis of type $e$ on variable $Z$ over the event window, relative to "tranquil times". The fact that the "tranquil times" baseline is common to all events makes the comparison among coefficients straightforward. Additionally, this allows us to plot the estimated coefficients throughout the crisis window and compare the dynamics of variables around different types of crises. Given that we are working with normalized data, a transformation is necessary so as to gauge the economic significance of the coefficients. Similar to the approach in Broner et al. (2013), we recover the economic significance of our coefficients as the product of the estimated coefficient and the median standard deviation of the non-standardized version of the dependent variable, across countries with the same type of crisis.

\section{Banking crises and sovereign defaults: exploring the links}

In this section, we provide a set of stylized facts on the behavior of key economic variables around each of the four types of crises defined in the previous section. In Appendix 2, we plot (a transformation of) the coefficients obtained for each variable and contrast the behavior of our variables around the different types of crisis events $^{27}$. First, we look at the dynamics around banking crises, distinguishing between "single" ones $(B)$ and those that degenerate into sovereign debt crises $(B D)$. We then repeat the analysis for our set of debt crises, distinguishing between "single" debt crises $(D)$ and those that compound into twin debt-bank ones $(D B)$.

\footnotetext{
${ }^{27}$ Appendix 3 contains the regression results. In addition, for the discussion presented in this section, we have conducted a complete set of tests to determine the significance of the differences in levels and dynamics of each variable around the different types of crises (available upon request).
} 
In addition to the differences between single and twin events, the analysis presented below reveals that, when contrasting the behavior of variables around twin debtbank and twin bank-debt events, some dynamics are not shared by both types of twin events. This is a very relevant result, as most papers in the literature have not distinguished between twin events according to the original shock (the original crisis). Our findings show that, when taking into account the different sequence of crises during twin episodes, there are remarkable differences in behavior of the budget deficit, budget expense, inflation rate and capital flows ${ }^{28}$.

\subsection{Banking crises versus twin bank-debt crises}

\section{Balance sheet relations}

Figures 2 and 3 in Appendix 2 depict the dynamics of credit provided by the central bank to the domestic banking sector, scaled by the GDP and bank assets, respectively. Figure 2 shows that the liquidity support provided by the central bank is larger than "tranquil" levels well ahead of $B$ events, peaks at the time of the crisis, and falls quickly and significantly afterwards, approaching non-crisis levels from $T+2$ onwards. In contrast, the liquidity support provided ahead of $B D$ crises is much lower (in fact, this is the only type of crisis ahead of which the central bank support is not significantly larger than in "tranquil" times). The liquidity support from the central bank then significantly jumps during the first year of the crisis, and, unlike in $B$, remains at levels larger than "tranquil" times for the subsequent years. On average, levels ahead of $B$ are significantly higher than ahead of $B D$, while the opposite is true in the aftermath of banking crises. The story is similar when looking at support scaled by the size of the banking sector (figure 3).

These different patterns could be due to differences in the size and timing of the initial shock to the banking sector, policy choices by the central bank and government, structural features of the banking sector or, most likely, a combination of all these factors. Indeed, it is difficult to say whether the large amount of central bank support provided ahead of $B$, but not ahead of $B D$, is due to differences in the shocks hitting the banking sector (i.e. high and persistent tensions and a gradual deterioration of the banking sector in $B$ versus a sudden, unexpected, shock to an otherwise healthy system in $B D$ ), the size and complexity of the banking sector, strategies chosen to deal with banking sector tensions (i.e. support given through other channels, or mere mismanagement of banking problems, in $B D$ ). Similarly, our

28 Indeed, when we regress these variables on a dummy bundling together twin bank-debt and debtbank events, as previous literature has done, we do not obtain any significant results. 
analysis cannot discern what is behind the markedly diverging dynamics in the aftermath of the two banking crises. These could be due to differences in the severity of the banking crisis (i.e. tensions in the banking system recede after $\mathrm{B}$, but remain high after the banking crisis in $B D$ and ahead of the ensuing default); resolution strategies focused on bank restructuring, instead on continuing to extend official credit to keep the system afloat; or the size of the fiscal space available (i.e. the "late" response from the central bank in $B D$ crises could due to the government running out of resources in its initial attempt to sustain the banking sector and the central bank stepping in as the sovereign goes into default).

Additional information into the differences between the two types of banking crises could be obtained from the dataset used in Laeven and Valencia's (2013a) study on the fiscal costs of banking crises. We map our definition of crises into their dataset and obtain several static indicators describing the severity of banking crises, as shown in Table 6 of Appendix 1. According to this table, the difference between $B$ and $B D$ episodes is not that much in the intensity of the banking crises, as nonperforming loans and bank closures are similar in both types of events. The main difference is in the fiscal costs of solving the crises. Fiscal costs corresponding to $B D$ crises are almost double those of $B$ crises, including a much higher amount deployed to recapitalize the banks. The difference in fiscal and recapitalization costs could be due either to differences in the available fiscal space, or different strategies for resolving banking crises.

Further insight into the balance sheet interconnection between the banking and public sectors can be obtained from looking at the amounts of claims on government in banks' balance sheets around the two crisis episodes, whose behavior is depicted in Figures 4 (scaled by GDP) and 5 (scaled by bank assets). While banks' exposure to the government is actually significantly lower than in "tranquil" times ahead of both events, it does increase significantly during both crises windows. The main difference nevertheless lies in the pattern of these increases. Banks' holdings of public debt increase both before and after the banking crisis in $B D$ (particularly accelerating ahead of $T$ ), while in $B$ the increase occurs entirely in the aftermath. Thus, what differentiates $B D$ from $B$ is the fast accumulation of public debt holdings ahead of the banking crisis in the former event.

In $B D$ events, the fast accumulation both ahead and after the banking crisis could be due to either failed attempts by the government to strengthen the banking sector, or to banks buying government bonds because incentivized or forced to sustain the government, or both. In contrast, in $B$ events, no significant government 
bond buying by banks takes place before the crisis, whereas the significant postcrisis accumulation could be the result of either a recapitalization program (and thus the bank resolution strategies switch from liquidity provisioning to balance sheet repair), or, simply, lending decisions by banks, which prefer to retrench from the private sector and instead invest in safer assets.

To sum, the interplay between banks' and both central bank's and government's balance sheets reveals that there are systematic differences around the two episodes, which could reflect different pre- and post-crisis strategies to deal with banking sector problems, together with different banking sector characteristics and different initial shocks. Figures 2 to 5 clearly show the shift in the balance sheet interconnections between the banking and public sectors during the two events. Ahead of $B$, low pre-crisis amounts of claims on government combine with high liquidity support, while in the aftermath liquidity support drops quickly and claims on government start rising. In $B D$, the fast and substantial accumulation of government paper ahead of the banking crisis combines with no liquidity support from the central bank, while in the aftermath of the banking crisis, the accumulation of claims on government moderates and central bank support shoots up.

\section{The banking sector}

We next study whether there are any systematic differences in the banking sectors characteristics around the two crisis episodes. We start by looking at size, measured by the ratio of assets to GDP (Figure 6). Several features stand out. Firstly, on average, banking sectors around $B D$ episodes are larger than those around $B$ episodes. The difference between the two narrows just ahead of the banking crisis, but widens again in the aftermath, due to the opposite dynamics discussed below.

Secondly, there is a substantial build-up in assets ahead of both episodes, but the increase ahead of $B$ events is significantly steeper than the one ahead of $B D$ crises. Thirdly, in $B$ events, asset downsizing starts the year of the crisis, continues through the following years and is as large as the preceding build-up, such that the banking sector returns to its pre-crisis size rather quickly. In contrast, in $B D$ events, not only does asset downsizing start two years after the banking crisis, but also the process is more gradual than in $B$. Even at $T+3$, and as the sovereign defaults, the size of the $B D$ banking sector is larger than both pre-crisis levels and "tranquil" times - $B D$ is in fact the only type of crisis in which assets do not return to pre-crisis levels, but instead remain significantly above "tranquil" levels. This could indicate that the policy 
response to the unfolding crisis is to try to keep the banking sector afloat, postponing deleveraging until the crisis has already engulfed the public sector as well.

Figure 7 shows the evolution of credit extended to the private sector (as a share of GDP), which confirms that banking sectors in $B D$ events are, on average, deeper than those around $B$ crises. While credit expands ahead of both events, the increase is more pronounced ahead of $B$ crises. In turn, the post-crisis fall in credit is similar in both crises.

The evolution of bank deposits to GDP is depicted in Figure 8. In both events, a significant pre-crisis expansion is followed by a deposit run. Nevertheless, the increase is faster ahead of $B$, and the subsequent run is larger and occurs earlier in $B$. While in $B$, the run leads to post-crisis levels of deposits well below "tranquil" times, in $B D$, levels are larger than "tranquil" times both ahead and after the banking crisis.

Overall, our results show that banking systems around $B D$ events are significantly larger and deeper than around $B$ events, which suggests that the former potentially need larger government support in situations of stress. Larger and deeper banking sector have a more damaging effect on the economy, giving the government more incentives to intervene and prop up the banking sector (Gennaioli et al, 2014).

\section{Public finances}

Figures 9 to 11 depict the behavior of budget balances, together with those of budget expense and revenues. Budget balance positions are similar ahead of the two events and both worsening throughout the crisis window, such that post-crisis levels are significantly lower than in "tranquil" times. In $B$, the worsening is gradual and most of it occurs pre-crisis, driven mainly by decreasing budget revenues, as public spending stays flat. In $B D$, while pre-crisis dynamics are similar to $B$, there is a sharp deterioration in the immediate aftermath of the banking crisis, due to a large increase in public spending.

The dynamics of public debt, shown in figure 12, are even more diverging. The sharp increase in $B D$ from $T-1$ onwards stands out. Indeed, public debt accumulates mainly as the banking crisis gets underway, such that, going into the sovereign default, the level of public debt is much larger than in "tranquil" times. In contrast, government debt remains flat throughout the crisis window in $B$ crises. 
Thus, the banking crises in the two events occur against similar pre-crisis budget positions and dynamics, while public debt is actually lower ahead of $B D$ than ahead of $B$ crises. Once banking crises are underway however, diverging patterns of public finances emerge. While the worsening in budget balance moderates in $B$, there is a sharp increase in budget deficit in $B D$, on the account of shoot up in public spending after the banking crisis. The difference is even more apparent in terms of public debt, where flat dynamics ahead and after $B$ contrast with the large accumulation in $B D$, which starts during the year of the banking crisis and continues unabated up to the sovereign default. This could suggests that banking crises put more strains on government finances in $B D$ events, whereas any support for the banking sector that is offered in $B$ episodes is not significantly reflected in either government debt or deficit.

\section{Domestic economy and the external sector}

As detailed in the discussion of section 2, banking crises could potentially affect the sovereign indirectly, through the effect they have on the economy and investors' sentiment.

Figure 13 depicts the evolution of the real growth rate around the two events. Real growth is significantly below "tranquil" levels ahead of $B$ and worsens immediately after the crisis. Nevertheless, the recovery is rather swift, as growth significantly exceeds pre-crisis rates already by $T+2$. In contrast, growth collapses at time $T$ and remains significantly lower than "tranquil" times in the aftermath of the $B D$ banking crisis. This suggests that the banking crises that are part of $B D$ events are more disruptive for the economy than single events. This growth pattern is accompanied by a large jump in inflation in the aftermath of the banking crises in $B D$ (see Figure 14). This might reflect the authorities' attempts to monetize the debt, or simply a run on the local currency, as the confidence in the sovereign is lost. In fact, inflation rates remain significantly above "tranquil" levels in the aftermath of the $B D$ banking crises. In contrast, while inflation is slightly higher than in "tranquil" times ahead of $B$, it gradually moderates throughout the crisis window, reaching levels that are similar to "tranquil" ones immediately after the crisis.

One widely documented source of instability for the emerging economies relates to the behavior of international portfolio capital flows, which could potentially be disrupted by banking crises. Figure 15 shows that there is a gradual and similar increase in portfolio capital inflows ahead of both events, which leads to levels that 
are significantly above "tranquil" times ahead of both crises. In the aftermath of banking crises, the soft landing in $B$ contrasts with the sudden stop in $B D$.

Figure 16 looks at the share of short-term debt in total foreign debt. While Reinhart and Rogoff (2011) point out that short-term debt tends to increase dramatically ahead of crises, we see that this is the case with $B D$ crises only. While there is a significant shift towards short-term debt ahead of both events, the pace and magnitudes are markedly different. In $B$, the shift towards shorter maturities is small and gradual, and is followed by an equally gradual reversal to pre-crisis levels. In contrast, there is a large accumulation of short-term debt ahead of $B D$, reaching levels significantly above "tranquil" ones in the run-up to the banking crisis, reflecting foreign creditors' higher unwillingness to lend in $B D$ relative to $B$. The behavior of both portfolio capital flows and short-term foreign debt thus seem to suggest that $B D$ banking crises result in larger losses of credibility among foreign investors than $B$ crises, with consequences for the sovereign as well.

Overall, we find that that the macroeconomic environment ahead of $B$ crises is characterized by low growth and high inflation, but that, nevertheless, the economy rebounds already by the second year after the banking crisis. In contrast, growth collapses and inflation shoots up following the $B D$ banking crises. Growth rates then remain depressed, and inflation rates persistently high, suggesting that $B D$ banking crises are more damaging to the economy. These crises are also associated with a larger loss in foreign investors' confidence, as reflected in the behavior of portfolio inflows and short-term foreign debt dynamics.

\subsection{Sovereign debt crises versus twin debt-bank crises}

\section{Balance sheet relations}

Figures 17 and 18 show that there is a sharp contrast between $D$ and $D B$ crises in terms of support provided by the central bank to the domestic banking system. While pre-crisis levels are of similar magnitude and both significantly above "tranquil" levels, what differentiates $D$ and $D B$ events are the dynamics of this indicator and its post-crisis levels. Liquidity support is flat throughout $D$ events, whereas it increases dramatically in $D B$, especially accelerating during $T-1$ to $T+1$. In the aftermath of $D B$ defaults, liquidity support remains persistently well above pre-crisis levels (and "tranquil" levels). 
The fact that the amount of central bank support provided around the two defaults is significantly larger than non-crisis levels is an indication that banking sector tensions accompany both defaults, including single events. Presumably, difficulties to obtain financing in wholesale markets (due to increased uncertainty and a loss of investor confidence) and a deteriorating environment put strains on banking sectors around both episodes. Nevertheless, the significant differences in dynamics and post-crisis levels between the two events could indicate that, on the one hand, $D B$ defaults are more damaging to banks' balance sheets, and, on the other hand, they leave the sovereign with little margin to support the banking sector.

More insight into the damage to banks' balance sheets associated with DB defaults could be obtained from examining the evolution of claims on government as a share of GDP and assets (Figures 19 and 20). Unfortunately, while the estimated coefficients plotted in these figures show substantial differences between $D$ and $D B$, few of these differences are statistically significant, as standard errors are very large. The most striking difference between the two events is that levels around $D B$ episodes are much larger than either around $D$ or "tranquil" times, suggesting that $D B$ crises take place against banking sectors that are significantly more exposed to the government. Additionally, while banks significantly accumulate public debt in the run-up to both defaults, the pace is more accelerated ahead of $D B$ than ahead of $D$. Post-default, there is a gradual and significant decline in banks' holdings of public debt in both events.

Finally, regarding the public support to the banking system, the static indicators presented in Table 6 of the Appendix 1 show that the fiscal and recapitalization costs of banking crises occurring after sovereign defaults are strikingly small relative to the other two types of banking crises.

Our results thus suggest that, around the two events, there are large and systematic differences in the levels and dynamics of both the liquidity support provided by the central bank and banks' exposure to the sovereign. These differences could suggest that banking sectors come under more stress after $D B$ defaults than after $D$ ones, due to, among other things, their larger exposure to the sovereign and smaller government support.

\section{The banking sector}

Unfortunately, the estimates of banking sector indicators are imprecise and plagued by high standard errors. Figure 21 shows that bank assets expand ahead of both 
events, although the expansion is more accelerated ahead of $D B$. In the aftermath, assets decrease significantly in both events, but sharper in $D B$. The initial size of the banking sector is larger in $D$ than in $D B$, but, due to the subsequent faster increase in $D B$, levels are similar entering the crisis and post-default.

Turning to the evolution of credit to the private sector (Figure 22), the roughly flat dynamics ahead of $D$ contrast with the significant credit boom ahead of $D B$. Post default, credit contracts in both episodes, although the crunch is larger and more sustained in $D B$ than in $D$. On average, the credit-to-GDP ratio is significantly larger around $D$ episodes than around $D B$ ones. In turn, there is a significant increase of deposits (as \% of GDP) (Figure 23) ahead of $D B$, followed by a fast and substantial deposit run, indicating that banking sectors in these events are confronted with a larger loss in confidence. This contrasts with the flat dynamics around $D$ crises - in particular, $D$ is the only type of crisis that appears to not lead to a deposit run.

Thus, overall, the average banking sector around $D B$ events appears to be smaller than the one ahead of $D$ events, suggesting that the larger amounts of liquidity support provided by the central bank after defaults in $D B$ may be due to the more damaging impact of the default on the banking sector in these crises, rather than to the size of the banking sector. The fact that $D B$ defaults are also followed by large deposit runs confirms the more disruptive impact of the sovereign on the banking sector. In contrast, the impact of $D$ defaults on the banking sector is more muted.

\section{Public finances}

Figures 24-26 depict the behavior of budget balances, together with the corresponding revenues and expenses. Budget deficits are larger ahead of $D$ than ahead of $D B$ (indeed, they are larger than in "tranquil" times). In both events, corrections of fiscal deficits start the year of the default, but the tightening is significantly more pronounced after the $D B$ defaults. Underlying these dynamics is the markedly different behavior of budget expense (while levels and dynamics are rather similar on the revenue side). Public spending is flat and significantly larger than in "tranquil" times ahead of both defaults. However dynamics start to diverge significantly starting with the default: in $D$, public spending decreases gradually, such that, after two years, expense is lower than pre-crisis levels and similar to "tranquil" ones. In contrast, the default in $D B$ is accompanied by a drop in public spending, which is especially sharp during $T+1$, and, post-crisis, public spending remains at levels significantly lower than "tranquil" ones. Thus, in the aftermath of the default, public expense is cut more drastically in $D B$ than in $D$ - in fact, during the 
years following the default, public spending is significantly larger in $D$ than in $D B$. This could be an indication of the lack of fiscal space in the aftermath of $D B$ defaults, or the adoption of a more austere stabilization package, both of which may negatively affect the banking sector in the short run.

Figure 27 shows that there is a significant and sustained increase in government debt ahead of both crises and, moreover, debt levels remain larger than pre-crisis ones in the aftermath of both defaults. While initial levels are similar, the ratio becomes significantly larger in the immediate aftermath of the $D B$ default than in that of the $D$ one. Starting with $T+1$ though, the reduction in debt is significantly faster in $D B$ than in $D$, which could be another potential signal of a tighter austerity package implemented in the aftermath of $D B$ defaults.

\section{Domestic economy and the external sector}

Figures 28 and 29 trace the dynamics of real growth and inflation rates around the two episodes. Growth falls rapidly ahead of $D$ crises and recovers equally rapidly in the aftermath, while inflation stays mostly flat throughout the crisis window. In contrast, $D B$ defaults have a larger immediate negative impact on growth, while the recovery is slower. These growth dynamics are accompanied by inflation rates that are slowly moderating, going from levels that are significantly above "tranquil" times at $T-3$ to levels that are significantly below at $T+3-$ a further indication of a possible tight austerity package implemented in the aftermath of defaults in $D B$ crises.

As shown in Figure 30, there is a gradual but constant decrease in portfolio capital inflows around $D$ crises, from levels significantly above "tranquil" times down to levels similar to non-crisis ones, suggesting that investors start retrenching already several years before the default. In contrast, in $D B$ events foreign capital keeps flowing in up until $T-1$, and the default is accompanied by a sharp drop in portfolio inflows (followed by a later rebound to pre-crisis levels). What is more striking in $D B$ is that the levels of capital flows are significantly below "tranquil" times both before and after the default. Thus, there is limited foreign capital flowing into the economy around these events.

Turning to short-term external debt dynamics, Figure 31 shows that flat and similar levels ahead of the two defaults are followed by completely diverging dynamics in the aftermath. In particular, the composition of foreign borrowing dramatically changes towards short-term maturities in the wake of $D B$ defaults and ahead of the ensuing banking crisis. The opposite takes place in the aftermath of $D$, where the 
share of short-term external debt decreases significantly after the default, to levels well below "tranquil" values. Together with the behavior of portfolio inflows, these dynamics point to a larger loss in credibility suffered by the sovereign in $D B$, which negatively impacts the banking sector and the economy.

\section{Conclusions}

In light of the recent turmoil in a number of advanced countries, understanding the channels through which distress transmits from the sovereign to financial institutions, and-vice-versa is of utmost importance. In this paper, we study past episodes of banking and sovereign distress in emerging economies, making the distinction between "single" episodes and those in which banking and sovereign debt crises combine ("twin" crises).

Our contribution is two-fold. Firstly, we find that there are systematic differences between "single" crises and "twin" ones, across several dimensions, including the balance sheet interconnection between the banking and public sectors, the characteristics of the banking sector, the state of public finances, and the macroeconomic environment. Secondly, we show that considering the sequence of crises within twin events, that is, taking into account whether the trigger of a twin episode is a debt crisis or a banking one, is important for understanding the potential drivers, transmission channels and economic consequences of these crises.

The stylized facts presented in this paper provide support to several recent theories according to which, in the presence of large banking systems, governments have more incentives to avoid defaults, as their effects on the economy would be amplified through the impact on banks' balance sheets (Gennaioli et al., 2014). Our results also provide support to theories arguing that monetary and fiscal coordination, and the ensuing Central Bank balance sheet expansion, are an integral part of crisis resolution strategies (Corsetti and Dedola, 2013). Last but not least, our findings show that, during the spread of sovereign crises to the banking sector, the shift from providing credit to the private sector to providing financing to the public sector is a well established regularity. This result provides support for modeling strategies along the lines of Broner et al. (2014). 


\section{REFERENCES}

Acharya, V., Drechsler, I. and Schnabl, P. (2014), "A Pyrrhic Victory: Bank Bailouts and Sovereign Credit Risk", Journal of Finance, forthcoming.

Alessandri, P. and Haldane, A. (2009), "Banking on the State", Bank of England.

Alter, A. and Beyer, A. (2013), "The Dynamics of Spillover Effects during the European Sovereign Debt Turmoil”, mimeo.

Andritzky, J.R. (2012), "Government Bonds and Their Investors: What Are the Facts and Do They Matter?", IMF Working Paper no. 12/158.

Angeloni, C. and Wolff, Guntram G. (2012), "Are banks affected by their holdings of government debt?, Bruegel Working Paper no. 2012/07.

Arellano, C. and Kocherlakota, N.R. (2012), "Internal Debt Crises and Sovereign Defaults", Federal Reserve Bank of Minneapolis, mimeo.

Baldacci, E. and Gupta, S. (2009), "Fiscal Expansions: What Works", Finance \& Development, Vol. 46 (4), pp. 35-37.

Broner, F., Didier, T., Erce A. and Schmukler, S. (2013), "Gross Capital Flows: Dynamics and Crises", Journal of Monetary Economics, Vol. 60(1), pp. 113-133.

Broner, F., Erce, A., Martin, A., and Ventura, J. (2014), "Sovereign Debt Markets in Turbulent Times: Creditor Discrimination and Crowding Out", Journal of Monetary Economics, Vol. 61 (C), pp. 114-142.

Broto, C. and Perez Quiros, G. (2013), "Disentangling contagion among Sovereign CDS spreads during the European debt crisis", Bank of Spain Working Paper no. 1314.

Brutti, F. (2010), "Legal enforcement, public supply of liquidity and sovereign risk", Institute for Empirical Research in Economics, University of Zurich Working Paper no. 464.

Candelon, B. and Palm, F.C. (2010), "Banking and Debt Crises in Europe. The Dangerous Liaisons?", CESifo Working Paper no. 3001.

Caprio, G. Jr. and Honohan, P. (2008), "Banking Crises", Institute for International Integration Studies Discussion Paper no. 242.

Cavallo, E. and Izquierdo, A. (2009), "Dealing with an International Credit Crunch: Policy Responses to Sudden Stops in Latin America", Inter-American Development Bank, mimeo.

Carey, D. (2009), "Iceland: The Financial and Economic Crisis", OECD Working Paper no. 725.

Cecchetti, S.G, Kohler, M. and Upper, C. (2009)," Financial crises and economic activity", NBER Working Paper no. 15379.

Corsetti, G., and L. Dedola (2013), "The Mystery of the Printing Press: Self-fulfilling Debt Crises and Monetary Sovereignty”, CEPR Discussion Paper no. 9358.

Darracq-Pariès, M., Maurin, L and Moccero, D. (2013), "Financial Conditions Index and Credit Supply Shocks for the Euro Area", ECB Working Paper no. 1644.

Das, U., Papaioannou, M., and Trebesch, C. (2009), "Sovereign Default Risk and Private Sector Access to Capital in Emerging Markets", in: Primo Braga, C. A. and Dömeland, D. (Eds): "Debt Relief and Beyond: Lessons Learned and Challenges Ahead". World Bank.

De Paoli, B., Hoggarth, G. and Saporta, V. (2009), "Output costs of sovereign crises: some empirical estimates", Bank of England Working Paper no. 362. 
Diaz-Cassou, J., Erce, A. and Vazquez, J. (2008a), "Recent episode of sovereign debt restructuring: A case-study approach", Bank of Spain Occasional Document no. 0804.

Diebold, F., and Yilmaz, K. (2009), "Measuring financial asset return and volatility spill overs, with an application to global equity markets", Economic Journal, Issue 119 (January), pp. 158-171.

Drechsler, I., Drechsler, T., Marques-lbanez, D., and Schnabl, P. (2013), "Who Borrows from the Lender of Last Resort?", mimeo.

Erce A. (2012), "Selective Sovereign Defaults", Globalization and Monetary Policy Institute, Working Paper no. 127.

Feenstra, R.C and Taylor, A.M. (2012), "International Economics", Second edition, Worth Publishers.

Gennaioli, N., Martin, A. and Rossi, S. (2014), "Sovereign Default, Domestic Banks and Financial Institutions", Journal of Finance, Vol. 69(2), pp.819-866.

Goldstein, M. (2003), "Debt Sustainability, Brazil and the IMF", Peterson Institute Working Paper no. WP03-1.

Gray, D. and Jobst, A. (2013), "Systemic Contingent Claims Analysis - Estimating Market-Implied Systemic Risk", IMF Working Paper no.13/54.

Gray, D., Gross, M., Paredes, J., and Sydow, M. (2013), "Modelling Banking, Sovereign and Macro Risk in a CCA Global VAR", IMF Working Paper no. 13/218.

Heinz, F. and Sun, Y. (2014), "Sovereign CDS Spreads in Europe: The Role of Global Risk Aversion, Economic Fundamentals, Liquidity, and Spillovers", IMF Working Paper 14/17.

Honohan, P. (2008), "Risk Management and the Costs of the Banking Crisis", The Institute for International Integration Studies Discussion Paper no. 262.

IMF (2002), "Sovereign Debt Restructurings and the Domestic Economy Experience in Four Recent Cases", Policy Development and Review Department.

Kollmann, R., Roeger, W., and in't Veld, J. (2012), "Fiscal Policy in a Financial Crisis: Standard Policy vs. Bank Rescue Measures", American Economic Review, Vol. 102(3), pp. 77-81.

Laeven, L. and Valencia, F. (2012), "The Use of Blanket Guarantees in Banking Crises", Journal of International Money and Finance, Vol. 31(5), pp. 1220-1248.

Laeven, L., and Valencia, F. (2013a), "Systemic Banking Crises Database", IMF Economic Review, Vol. 61(2), pp. 225-270.

Laeven, L. and Valencia, F. (2013b), "The Real Effects of Financial Sector Interventions During Crises", Journal of Money, Credit and Banking, Vol. 45(1), pp. 147-177.

Livshits, I. and Schoors, K. (2009), "Sovereign Default and Banking", mimeo.

Meissner, C.M. and Bordo, M.D. (2006), "Financial Crises, 1880-1913: The Role of Foreign Currency Debt", WEF Working Paper no. 0002.

Mitchell and Brian R., (2007), "International Historical Statistics: 1750 - 2005", (London: Palgrave MacMillan).

Mody, A., and Sandri, D. (2011), "The Eurozone Crisis: How Banks Came to be Joined at the Hip", IMF Working Paper no. 11/269.

Moody's (2014), "European Sovereign Debt and Banking Crises: Contagion, Spillovers and Causality", Moody's Investors Service, Credit policy.

Noyer, C. (2010), "Sovereign crisis, risk contagion and the response of the central bank", mimeo. 
Obstfeld, M. and Gourinchas, P.O. (2012), "Stories of the Twentieth Century for the Twenty-First", American Economic Journal: Macroeconomics, American Economic Association, Vol. 4(1), pp. 226-65.

Panizza, U. and Borensztein, E. (2008), "The Costs of Sovereign Default", IMF Working Paper no. 08/238.

Popov, A., and Van Horen, N. (2013), "The impact of sovereign debt exposure on bank lending: Evidence from the European debt crisis", DNB Working Paper no. 382.

Reinhart, C.M. (2009), "The economic and fiscal consequences of financial crises", MPRA Paper no. 13025.

Reinhart, C.M. and Reinhart, V. (2009), "Fiscal stimulus for debt intolerant countries?", MPRA Paper no.16937.

Reinhart, C.M. and Rogoff, K.S. (2008a), "Banking Crises: An Equal Opportunity Menace", NBER Working Paper no.14587.

Reinhart, C.M and Rogoff, K.S. (2008c), "This Time is Different: A Panoramic View of Eight Centuries of Financial Crises”, NBER Working Paper no.13882.

Reinhart, C.M. and Rogoff, K. S. (2009), "The Aftermath of Financial Crises", American Economic Review, Vol. 99(2), pp. 466-72.

Reinhart, C.M. and Rogoff, K.S. (2011), "From Financial Crash to Debt Crisis", American Economic Review, Vol. 101(5), pp. 1676-1706.

Rosas, G. (2006), "Bagehot or Bailout? An Analysis of Government Responses to Banking Crises", American Journal of Political Science Vol. 50(1), pp. 175-191.

Van Rixtel, A., and Gasperini, G. (2013), "Financial Crises and bank funding: recent experience in the euro area", BIS Working Paper no. 406. 



\section{APPENDIX 1: TABLES AND FIGURES}

Table 1. Twin crises: Bank-to-Debt

\begin{tabular}{|c|c|c|c|}
\hline Country & $\begin{array}{c}\text { Bank } \\
\text { crisis }\end{array}$ & $\begin{array}{l}\text { Debt } \\
\text { crisis }\end{array}$ & Source \\
\hline Algeria & 1990 & 1991 & S\&P and L\&V \\
\hline Argentina & 1980 & 1982 & S\&P and L\&V \\
\hline Chile & 1981 & 1983 & S\&P and L\&V \\
\hline Dominican Republic & 2003 & 2005 & S\&P and L\&V \\
\hline Ecuador & 1982 & 1982 & S\&P and L\&V \\
\hline Ecuador & 1998 & 1999 & S\&P and L\&V \\
\hline Guinea & 1985 & 1986 & S\&P and L\&V \\
\hline Indonesia & 1997 & 1998 & S\&P and L\&V \\
\hline Kenya* & 1992 & 1994 & S\&P and L\&V \\
\hline Mexico & 1981 & 1982 & S\&P and L\&V \\
\hline Morocco & 1980 & 1983 & S\&P and L\&V \\
\hline Philippines & 1983 & 1983 & S\&P and L\&V \\
\hline Nigeria & 1991 & 1992 & S\&P and L\&V \\
\hline Senegal & 1988 & 1990 & S\&P and L\&V \\
\hline Uruguay & 1981 & 1983 & S\&P and L\&V \\
\hline Uruguay & 2002 & 2003 & S\&P and L\&V \\
\hline Venezuela, R.B. & 1994 & 1995 & S\&P and L\&V \\
\hline
\end{tabular}

Source: Laeven and Valencia (2013a), S\&P (2009)

*Low income country (according to World Bank) 
Table 2. Twin crises: Debt-to-Bank

\begin{tabular}{|c|c|c|c|}
\hline Country & $\begin{array}{l}\text { Debt } \\
\text { crisis }\end{array}$ & $\begin{array}{l}\text { Bank } \\
\text { crisis }\end{array}$ & Source \\
\hline Albania & 1991 & 1994 & S\&P and L\&V \\
\hline Argentina & 1989 & 1989 & S\&P and L\&V \\
\hline Argentina & 2001 & 2001 & S\&P and L\&V \\
\hline Bolivia & 1986 & 1986 & S\&P and L\&V \\
\hline Brazil & 1990 & 1990 & S\&P and L\&V \\
\hline Costa Rica & 1981 & 1987 & S\&P and L\&V \\
\hline Cameroon & 1985 & 1987 & S\&P and L\&V \\
\hline Ghana & 1979 & 1982 & S\&P and L\&V \\
\hline Guinea* & 1991 & 1993 & S\&P and L\&V \\
\hline Jordan & 1989 & 1989 & S\&P and L\&V \\
\hline Macedonia & 1992 & 1993 & S\&P and L\&V \\
\hline Niger $^{*}$ & 1983 & 1983 & S\&P and L\&V \\
\hline Panama & 1987 & 1988 & S\&P and L\&V \\
\hline Peru & 1976 & 1983 & S\&P and L\&V \\
\hline Tanzania* & 1984 & 1987 & S\&P and L\&V \\
\hline Turkey & 1982 & 1982 & S\&P and L\&V \\
\hline Togo* & 1988 & 1993 & S\&P and L\&V \\
\hline Russian Federation & 1998 & 1998 & S\&P and L\&V \\
\hline Ukraine & 1998 & 1998 & S\&P and L\&V \\
\hline
\end{tabular}

Source: Laeven and Valencia (2013a), S\&P(2009)

* Low income country (according to World Bank) 
Table 3. Crisis episodes 1975-2007, by type (number)

\begin{tabular}{lccccc}
\hline \hline & $\mathbf{1 9 7 0 s}$ & $\mathbf{1 9 8 0 s}$ & $\mathbf{1 9 9 0 s}$ & $\mathbf{2 0 0 0 s}$ & Total \\
"Single" bank crises & 3 & 17 & 55 & 2 & 77 \\
"Single" debt crises & 11 & 43 & 17 & 14 & 85 \\
"Twin" crises & 2 & 19 & 12 & 3 & 36 \\
Twin bank-debt & 0 & 9 & 6 & 2 & 17 \\
Twin debt-bank & 2 & 10 & 6 & 1 & 19 \\
\hline TOTAL & $\mathbf{1 6}$ & $\mathbf{7 9}$ & $\mathbf{8 4}$ & $\mathbf{1 9}$ & $\mathbf{1 9 8}$ \\
Total: bank crises & 5 & 36 & 67 & 5 & 113 \\
Total: debt crises & 13 & 62 & 29 & 17 & 121 \\
\hline \hline Sources: S\&P, Laeven and Valencia $(20132)$ and authors' colculations
\end{tabular}

Sources: S\&P, Laeven and Valencia (2013a) and authors' calculations.

Figure 1. Crisis episodes 1975-2007, by type (number)

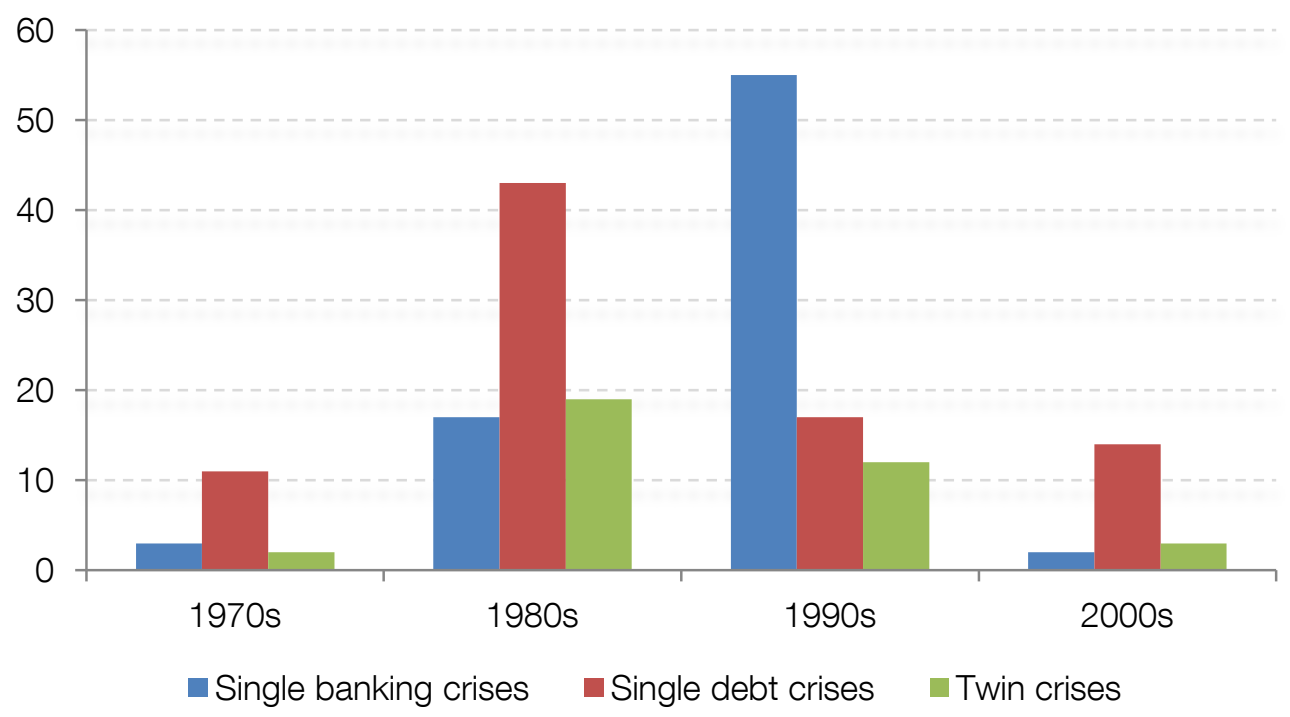


Table 4. Variables: definitions and sources

\begin{tabular}{|c|c|c|}
\hline Variable & Definition & Source \\
\hline \multicolumn{3}{|l|}{ "Exposure" variables } \\
\hline $\begin{array}{l}\text { Banking sector's claims on } \\
\text { government }\end{array}$ & $\begin{array}{l}\text { Claims on central government (line 22a) + } \\
\text { Claims on local government (line 22b) }\end{array}$ & International Financial Statistics \\
\hline Liquidity support & Credit from Monetary Authorities (line 26g) & International Financial Statistics \\
\hline \multicolumn{3}{|l|}{ Banking sector variables } \\
\hline Credit to the private sector & Claims to the private sector (line 22d) & International Financial Statistics \\
\hline Total assets & $\begin{array}{l}\text { Sum of all items on the asset side (line } 20+\text { line } \\
20 \text { c +line } 20 n+\text { line } 21+\text { line } 22 \text { ) }\end{array}$ & International Financial Statistics \\
\hline Deposits & $\begin{array}{l}\text { Demand Deposits (line 24) + Time, Savings and } \\
\text { Forex Deposits (line 25) + Restricted Deposits } \\
\text { (line 26b) }\end{array}$ & International Financial Statistics \\
\hline \multicolumn{3}{|l|}{ Fiscal variables } \\
\hline Budget balance & Government revenues - government expense & $\begin{array}{l}\text { EIU; IFS; WEO; Mitchell (2007); } \\
\text { Art.IV reports. }\end{array}$ \\
\hline Budget revenues & General government total revenues & $\begin{array}{l}\text { EIU; IFS; WEO; Mitchell (2007); } \\
\text { Art.IV reports. }\end{array}$ \\
\hline Budget expense & General government total expense & $\begin{array}{l}\text { EIU; IFS; WEO; Mitchell (2007); } \\
\text { Art.IV reports. }\end{array}$ \\
\hline Government debt & General government debt & World Development Indicators \\
\hline \multicolumn{3}{|c|}{ Macroeconomic variables } \\
\hline Real GDP growth & Annual change of real GDP & World Development Indicators \\
\hline Inflation & Annual change of the Consumer Price Index & World Development Indicators \\
\hline Portfolio capital inflows & $\begin{array}{l}\text { Sum of "portfolio investment liabilities" and } \\
\text { "other investment liabilities" }\end{array}$ & International Financial Statistics \\
\hline ST debt/Total external debt & $\begin{array}{l}\text { Ratio of short-term external debt over total } \\
\text { external debt }\end{array}$ & World Development Indicators \\
\hline
\end{tabular}


Table 5. The aggregate balance sheet of the banking sector

\begin{tabular}{ll}
\hline \multicolumn{1}{c}{ ASSETS } & \multicolumn{1}{c}{ LIABILITIES } \\
\hline Reserves (line 20) & Demand Deposits (line 24) \\
Claims on Monetary Authorities & Time, Saving and Forex Deposits (line 25) \\
Securities (line 20c) & Money Market Instruments (line 26aa) \\
Other claims (line 20n) & Bonds (line 26ab) \\
Foreign assets (line 21) & Restricted Deposits (line 26b) \\
Claims on other resident sectors (line 22) & Foreign Liabilities (line 26c) \\
Central Government (line 22a) & Central Government Deposits (line 26d) \\
Deposit Money Banks (line22e) & Credit from Monetary Authorities (line 26g) \\
State and Local Government (line 22b) & Liabilities to Other Banking Institutions (line 26i) \\
Nonfin. Public Enterprises (line 22c) & Liabilities to Nonbank Fin. Instit. (line 26j) \\
Private Sector (line 22d) & Capital Accounts (line 27a) \\
Other Banking Institutions (line 22f) & \\
Nonbank Financial Institutions (line 22g) & \\
\hline \hline Source: International Financial Statistics (IMF) & \\
\hline
\end{tabular}

Table 6. Intensity of banking crises: static indicators (as in Laeven and Valencia, 2013a)

\begin{tabular}{lccccc}
\hline \hline \multicolumn{1}{c}{ Crises types } & $\begin{array}{c}\text { NPL at } \\
\text { peak }\end{array}$ & $\begin{array}{c}\text { Change in number } \\
\text { of banks }\end{array}$ & $\begin{array}{c}\text { Fiscal } \\
\text { costs }\end{array}$ & $\begin{array}{c}\text { Recapitalization } \\
\text { costs (gross) }\end{array}$ & $\begin{array}{c}\text { Recapitalization } \\
\text { costs (net) }\end{array}$ \\
\hline & & & & & \\
"Single" banking crises & 27.59 & -18.90 & 12.99 & 6.06 & 4.87 \\
Bank to Debt crises & 35.34 & -22.00 & 25.51 & 14.22 & 9.33 \\
Debt to Bank crises & 35.90 & -43.40 & 4.87 & 1.92 & 1.92 \\
\hline Total average & 30.02 & -23.31 & 14.21 & 6.94 & 5.24 \\
\hline \hline
\end{tabular}

Sources: Laeven and Valencia (2013a), S\&P and authors' calculations. "NPL" refers to non-performing loans. Change in number of banks refers to the change between $T$ and $T+3$. Fiscal and recapitalization costs are measured as \% of GDP. 
APPENDIX 2: "BANKING" vs. "BANK-TO-DEBT" CRISES

Figure 2. Credit from the Central Bank (\% GDP)

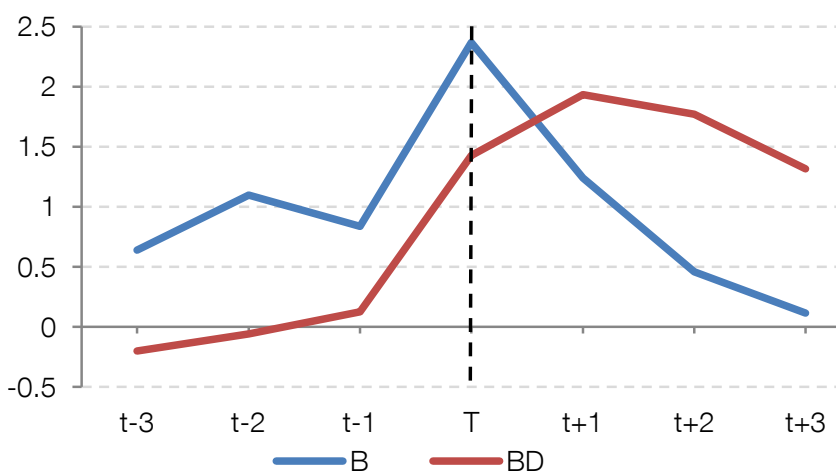

Figure 5. Claims on government ( $\%$ total assets)

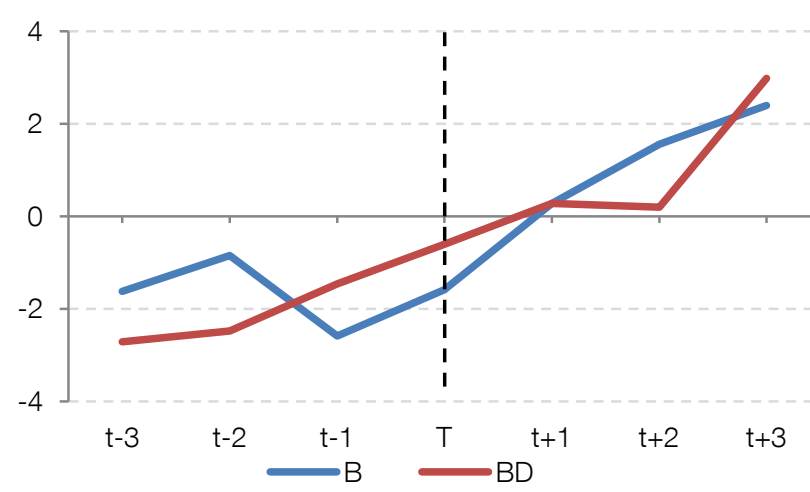

Figure 8. Banking sector deposits (\% of GDP)

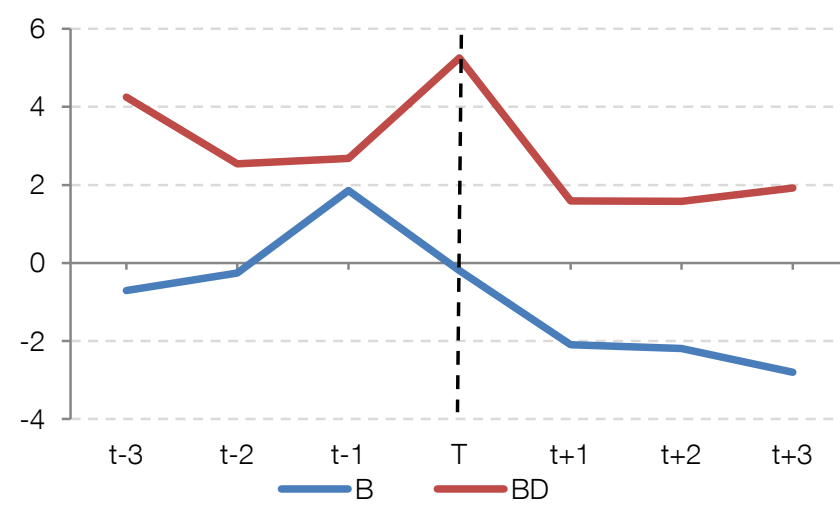

Figure 4. Claims on government (\% GDP)

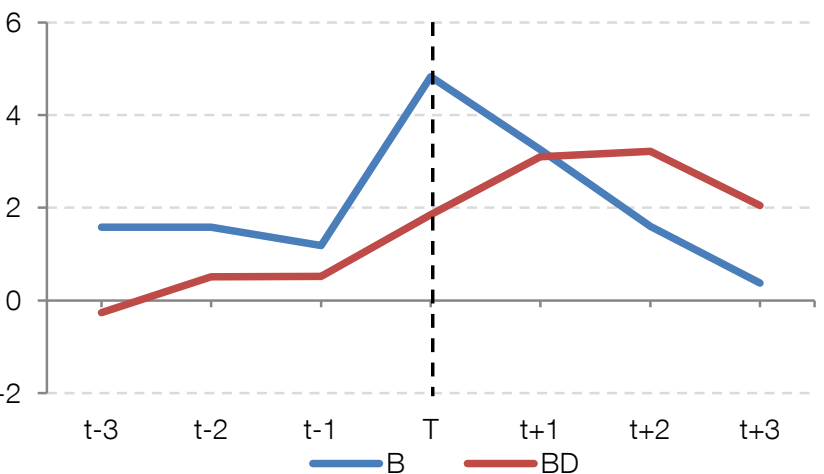

Figure 6. Banking sector assets (\%GDP)

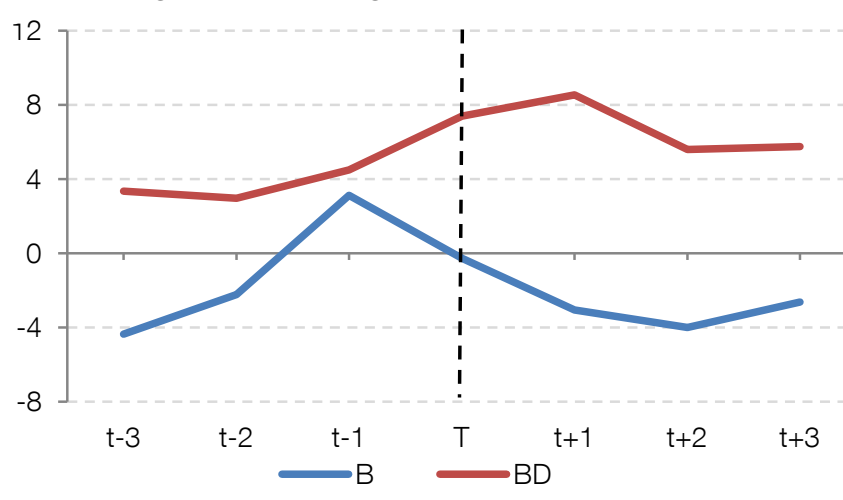

Figure 9. Budget balance (\% GDP)

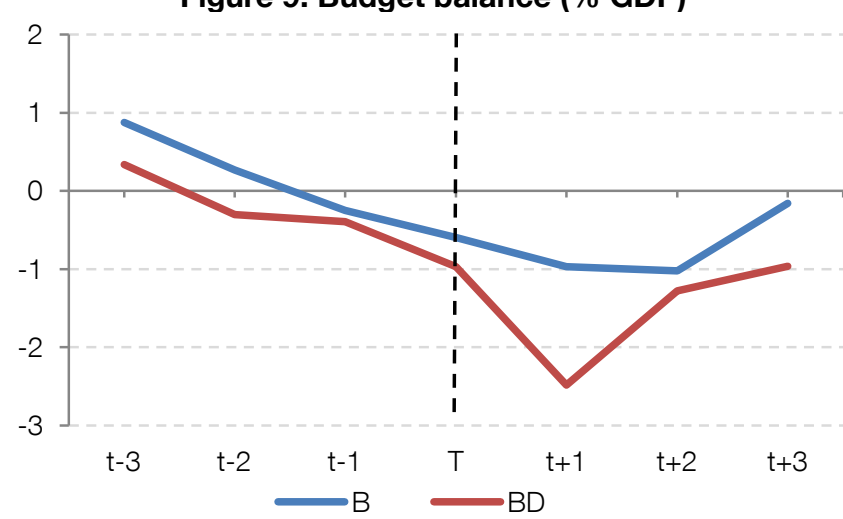

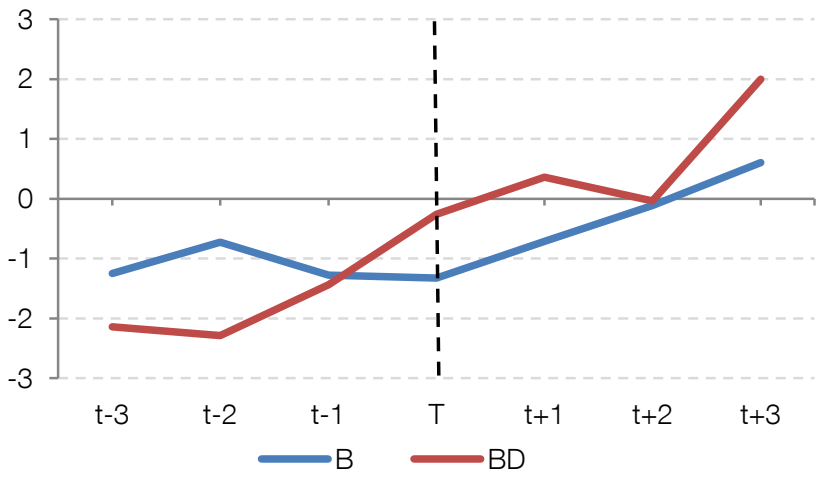

Figure 7. Credit to private sector (\% GDP)

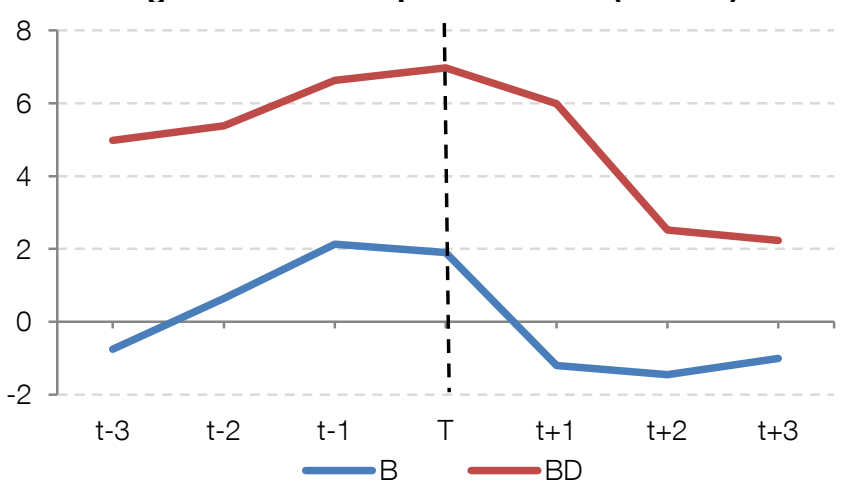

Figure 10. Budget expenditures (\% GDP)

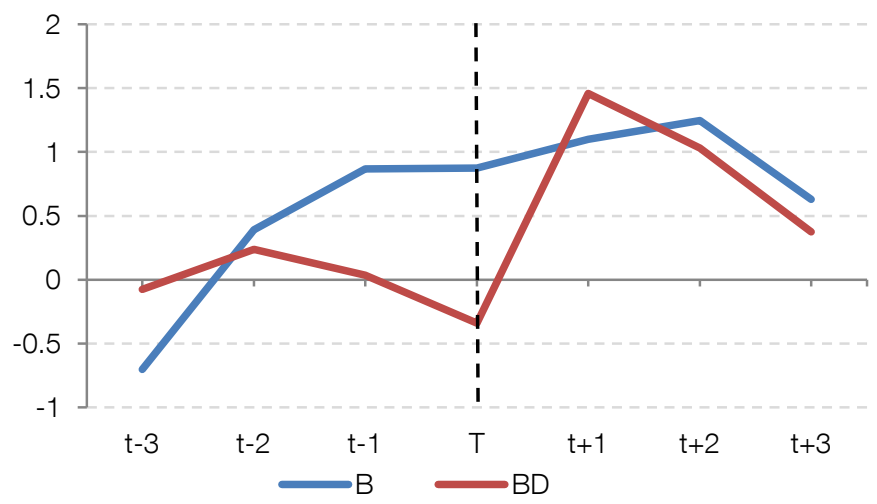


Figure 11. Budget revenues (\% GDP)

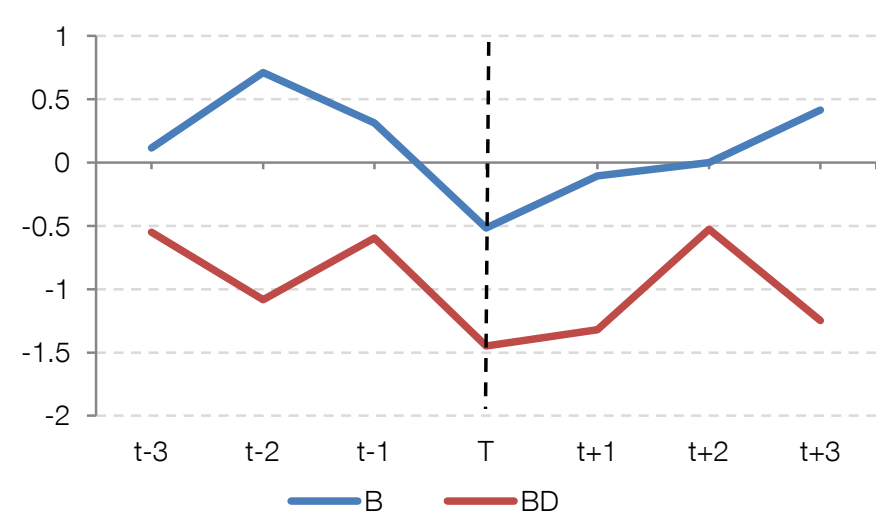

Figure 14. Inflation rate (\%)

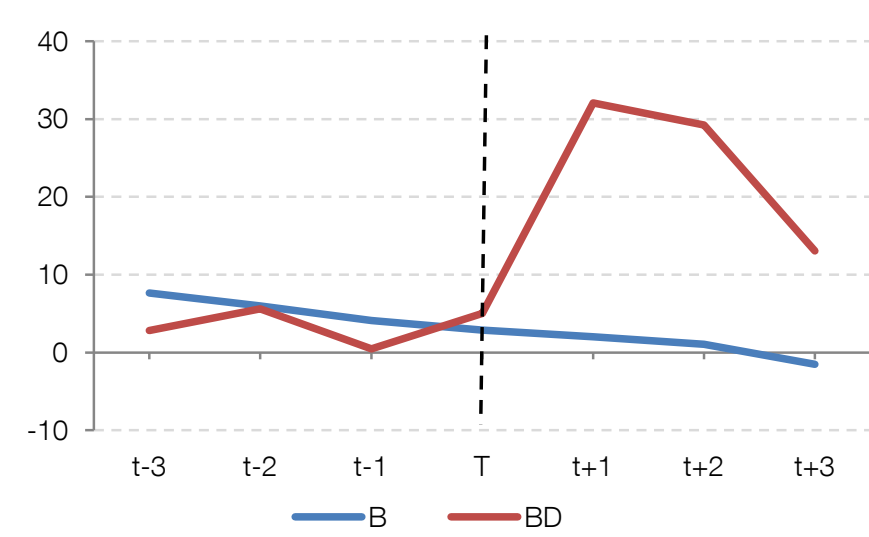

Figure 12. Public debt (\% GDP)

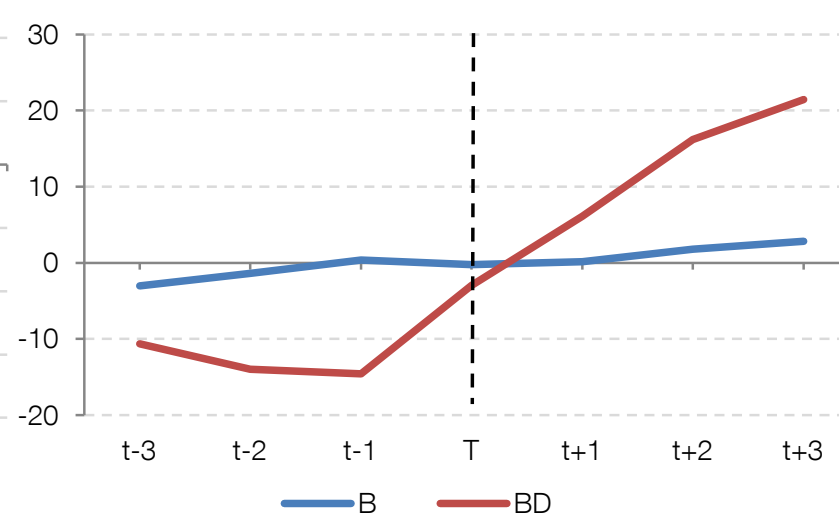

Figure 15. Portfolio capital inflows (\% GDP)

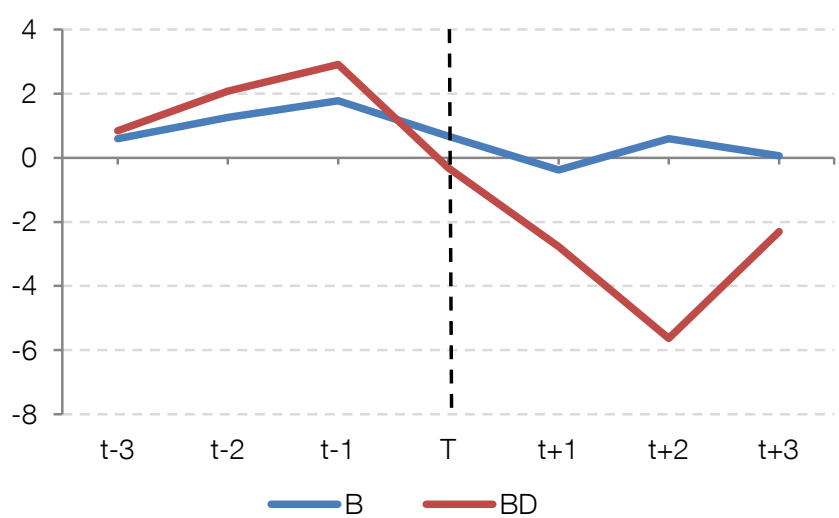

Figure 13. Real GDP growth (\%)

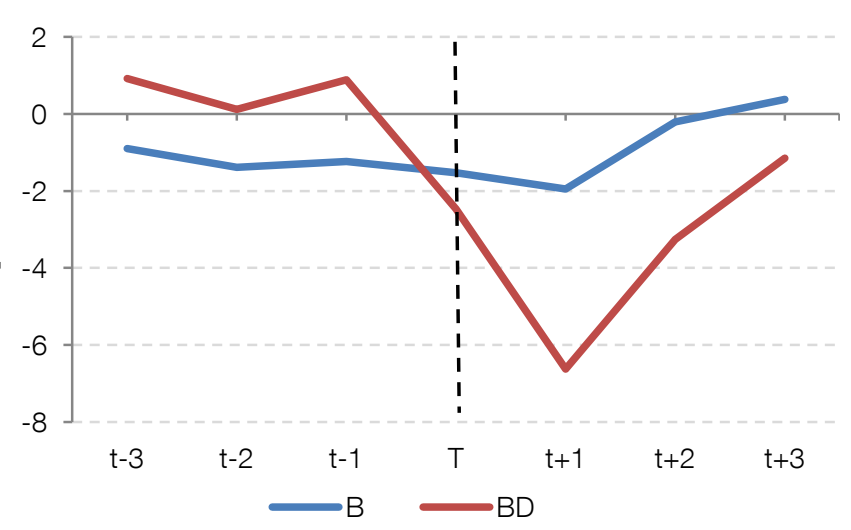

Figure 16. Short-term debt in total foreign debt (\%)

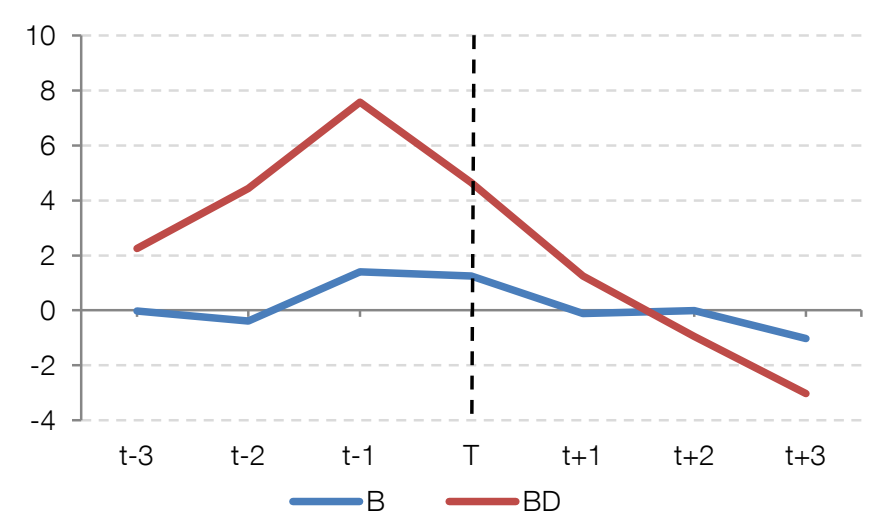


Figure 17. Credit from the Central Bank (\% GDP)

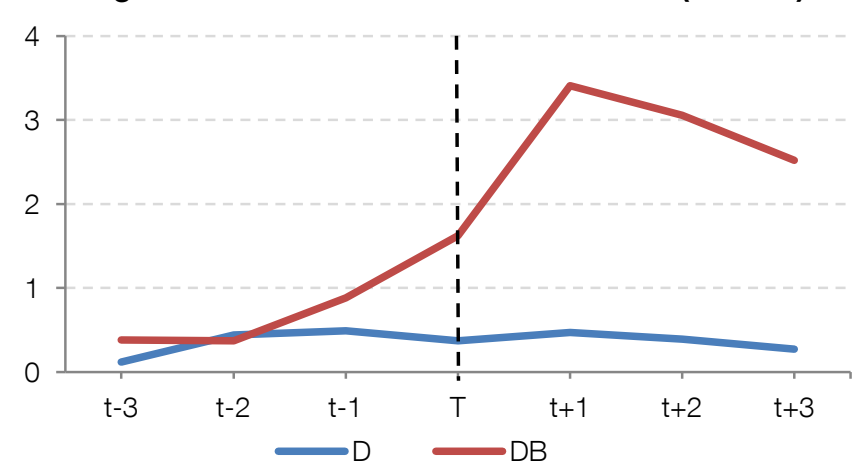

Figure 20. Claims on government (\% total assets)

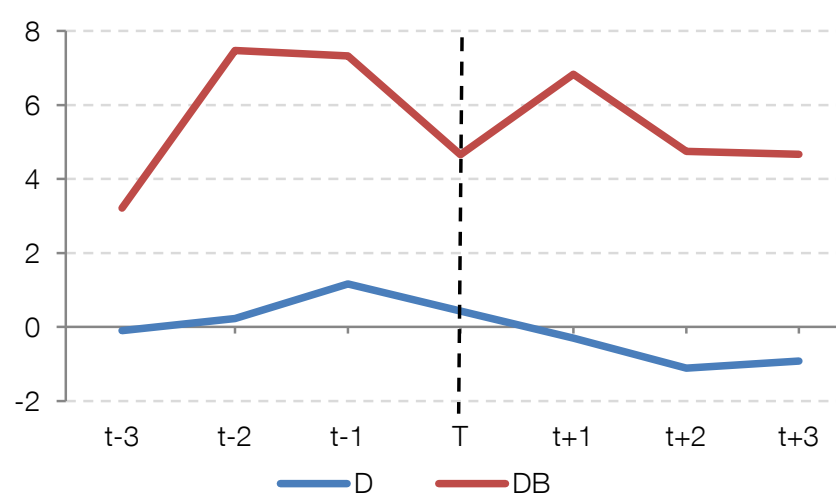

Fiqure 23. Banking sector deposits (\% GDP)

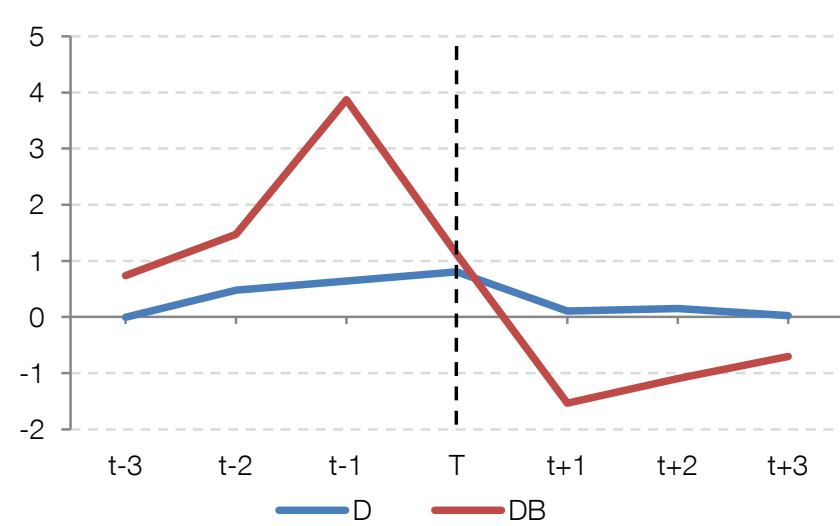

Fiqure 18. Credit from the Central Bank (\% assets)

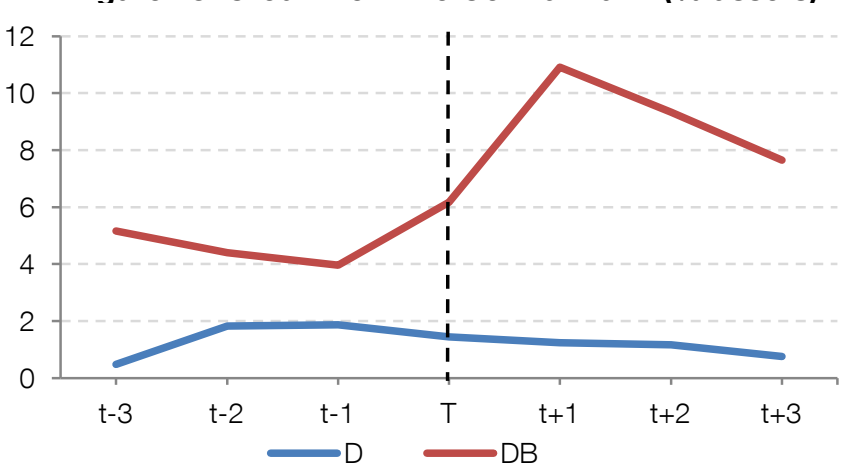

Figure 21. Banking sector assets (\% GDP)

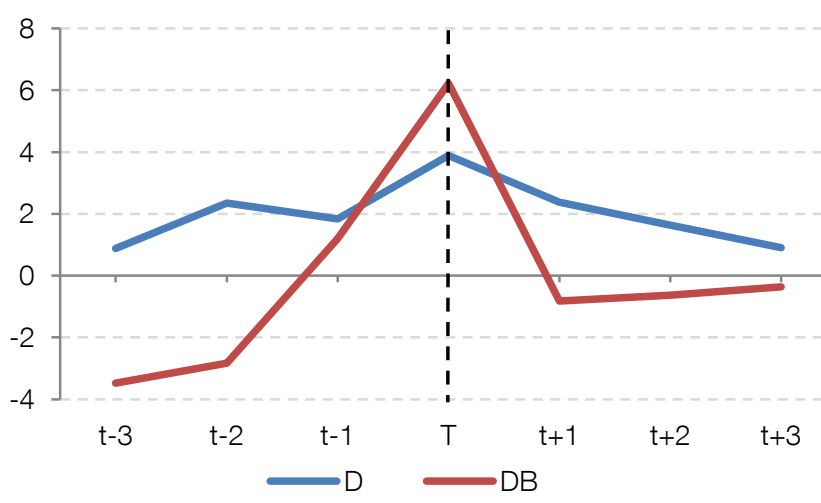

Figure 24. Budget balance (\% GDP)

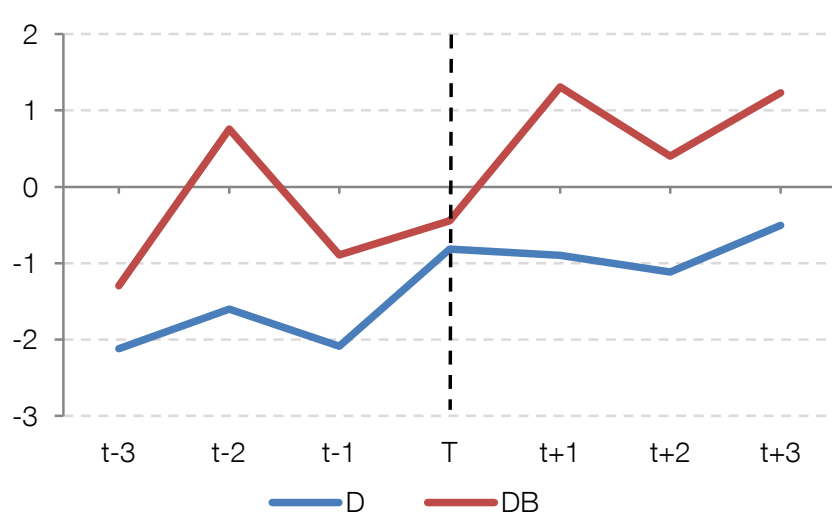

Figure 19. Claims on government (\% GDP)

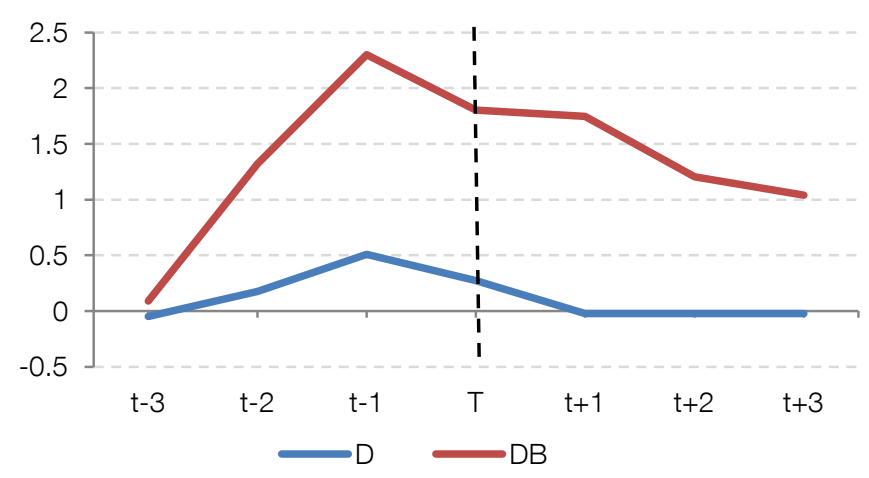

Figure 22. Credit to private sector (\% GDP)

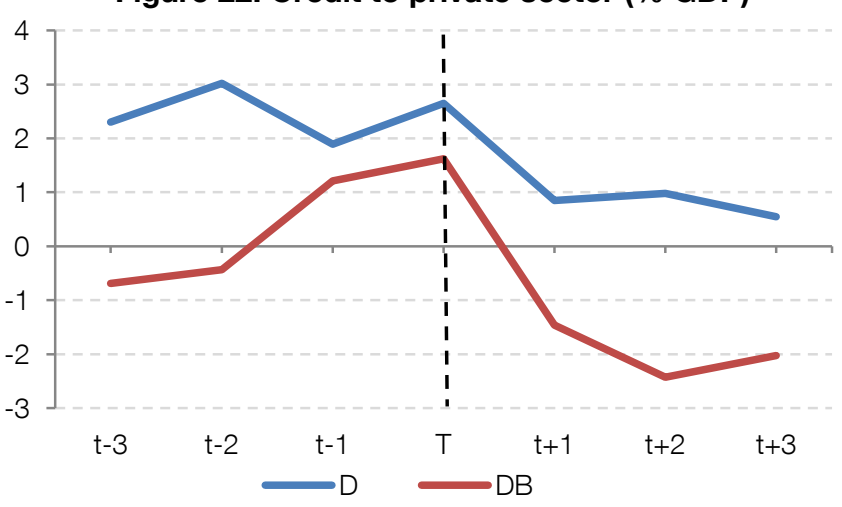

Figure 25. Budget expenditures (\% GDP)

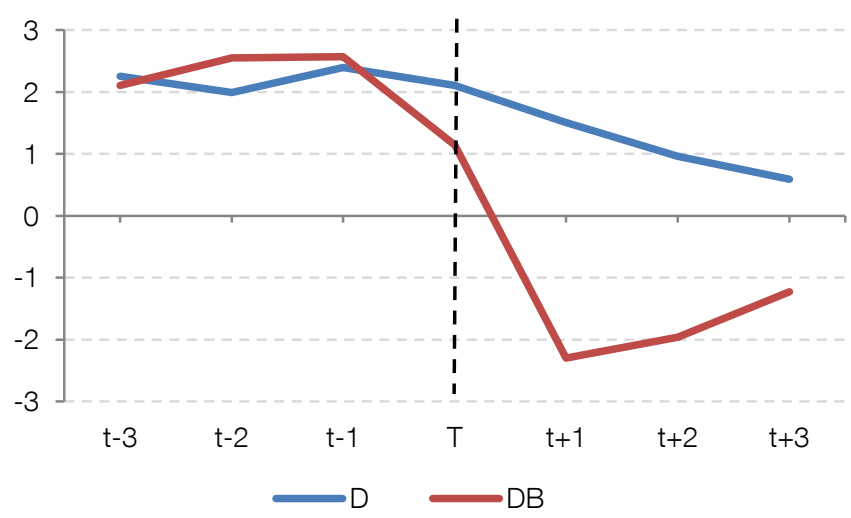


Figure 26. Budget revenues (\% GDP)

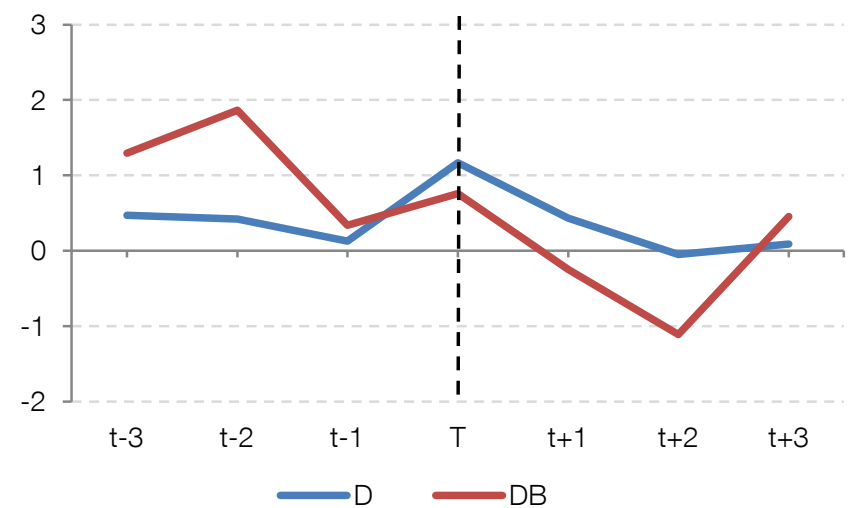

Figure 29. Inflation rate (\%)

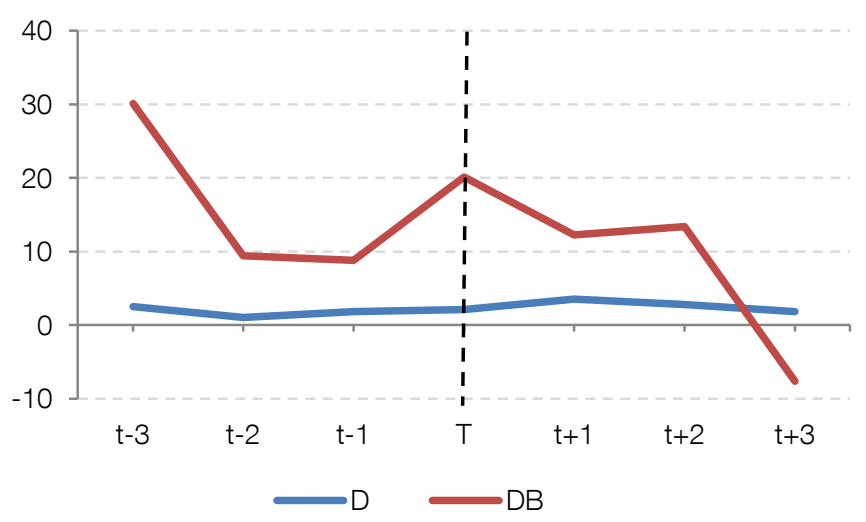

Figure 27. Public debt (\% GDP)

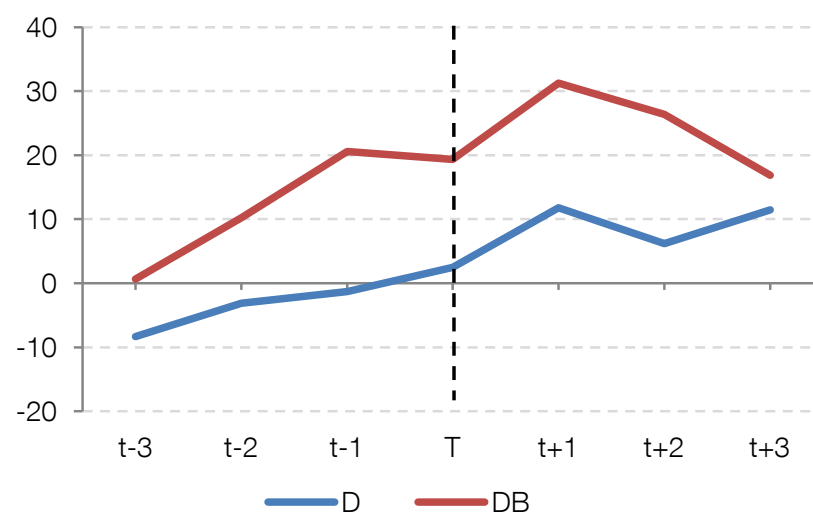

Figure 30. Portfolio capital inflows (\% GDP)

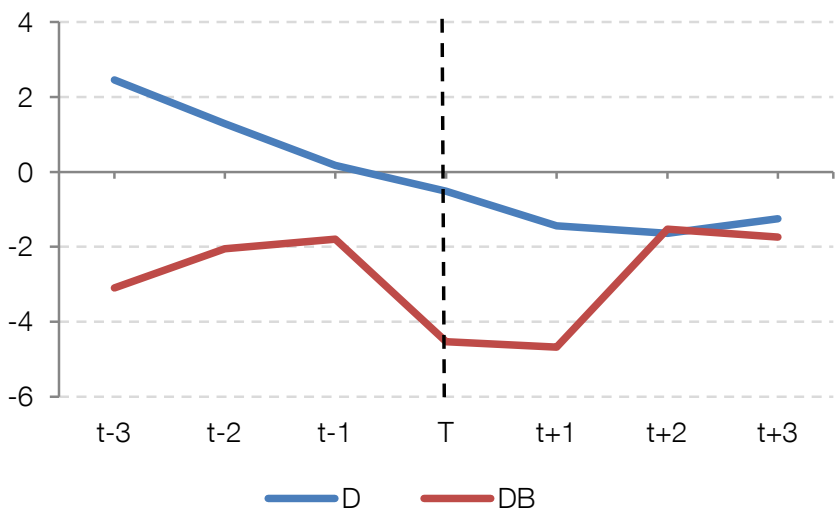

Figure 28. Real GDP growth (\%)

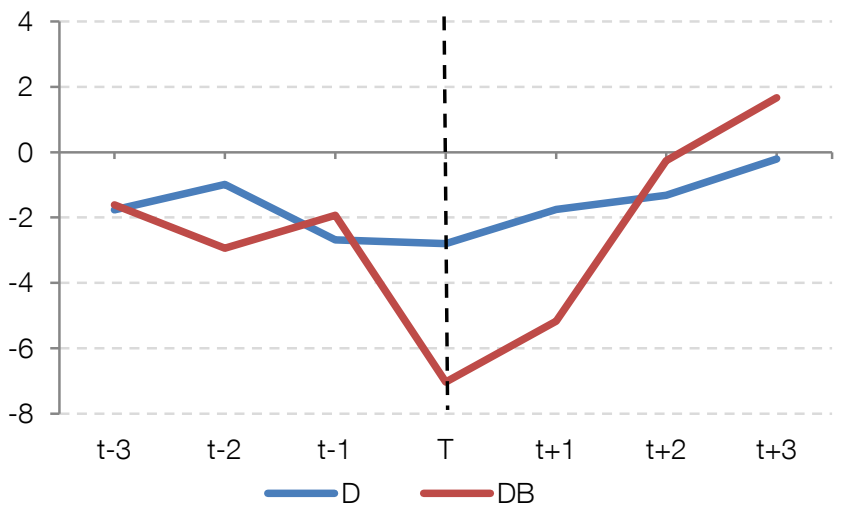

Figure 31. Short-term debt in total foreign debt (\%)

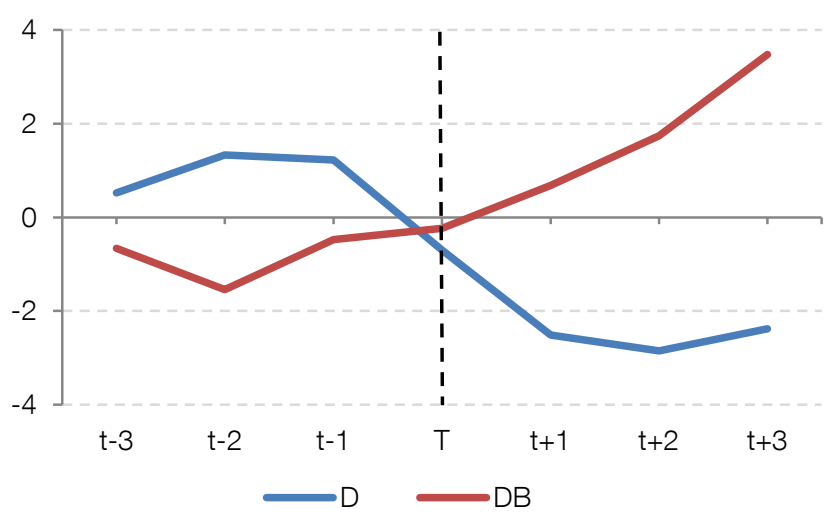


APPENDIX 3: ECONOMETRIC RESULTS

Table 7. Credit from the Central Bank (\% GDP)

\begin{tabular}{|c|c|c|c|c|}
\hline & D crises & DB crises & B crises & BD crises \\
\hline Year t-3 & $\begin{array}{l}0.102 \\
{[0.148]}\end{array}$ & $\begin{array}{l}0.113 \\
{[0.389]}\end{array}$ & $\begin{array}{c}0.263^{\star} \\
{[0.133]}\end{array}$ & $\begin{array}{c}-0.077 \\
{[0.270]}\end{array}$ \\
\hline Year t-2 & $\begin{array}{l}0.381^{*} \\
{[0.226]}\end{array}$ & $\begin{array}{l}0.111 \\
{[0.297]}\end{array}$ & $\begin{array}{c}0.451^{\star \star} \\
{[0.177]}\end{array}$ & $\begin{array}{c}-0.023 \\
{[0.268]}\end{array}$ \\
\hline Year t-1 & $\begin{array}{c}0.426^{\star \star} \\
{[0.195]}\end{array}$ & $\begin{array}{l}0.263 \\
{[0.310]}\end{array}$ & $\begin{array}{l}0.345^{\star} \\
{[0.176]}\end{array}$ & $\begin{array}{l}0.048 \\
{[0.208]}\end{array}$ \\
\hline Year Event & $\begin{array}{l}0.324 \\
{[0.207]}\end{array}$ & $\begin{array}{c}0.484^{*} \\
{[0.258]}\end{array}$ & $\begin{array}{c}0.974^{\star \star \star} \\
{[0.219]}\end{array}$ & $\begin{array}{l}0.547^{*} \\
{[0.283]}\end{array}$ \\
\hline Year $t+1$ & $\begin{array}{c}0.409^{*} \\
{[0.212]}\end{array}$ & $\begin{array}{c}1.018^{\star \star \star} \\
{[0.376]}\end{array}$ & $\begin{array}{c}0.510^{\star \star \star} \\
{[0.184]}\end{array}$ & $\begin{array}{c}0.740^{\star \star \star} \\
{[0.240]}\end{array}$ \\
\hline Year $t+2$ & $\begin{array}{l}0.338^{\star} \\
{[0.199]}\end{array}$ & $\begin{array}{c}0.912^{\star \star \star} \\
{[0.302]}\end{array}$ & $\begin{array}{l}0.189 \\
{[0.153]}\end{array}$ & $\begin{array}{l}0.678^{\star} \\
{[0.342]}\end{array}$ \\
\hline Year $t+3$ & $\begin{array}{l}0.235 \\
{[0.196]}\end{array}$ & $\begin{array}{c}0.753^{\star \star \star} \\
{[0.245]}\end{array}$ & $\begin{array}{l}0.047 \\
{[0.153]}\end{array}$ & $\begin{array}{l}0.504 \\
{[0.395]}\end{array}$ \\
\hline Observations & 1592 & 1592 & 1592 & 1592 \\
\hline R-squared & 0.06 & 0.06 & 0.06 & 0.06 \\
\hline No. of Countries & 75 & 75 & 75 & 75 \\
\hline No. of Events & 41 & 10 & 46 & 14 \\
\hline Country dummies & Yes & Yes & Yes & Yes \\
\hline Country trends & No & No & No & No \\
\hline
\end{tabular}

The table reports the coefficients obtained from a fixed-effects panel regression of the variable in the title on a seven-year window around crisis events, controlling for country fixed effects. Crisis events are spilt into independent debt crises; independent bank crises; twin debt-bank crises; and twin bank-debt crises. The variable is first normalized by dividing by the standard deviation at the country level. The sample period is 1975 to 2007 . Standard errors, clustered at the country-level, are reported in brackets. ${ }^{*},{ }^{* *}$, and ${ }^{* * *}$ mean significant at $10 \%, 5 \%$, and $1 \%$ respectively
Table 8. Credit from the Central Bank (\% total assets)

\begin{tabular}{|c|c|c|c|c|}
\hline & D crises & DB crises & B crises & BD crises \\
\hline Year t-3 & $\begin{array}{l}0.120 \\
{[0.155]}\end{array}$ & $\begin{array}{l}0.663^{\star} \\
{[0.353]}\end{array}$ & $\begin{array}{c}0.328^{\star *} \\
{[0.148]}\end{array}$ & $\begin{array}{l}-0.059 \\
{[0.291]}\end{array}$ \\
\hline Year t-2 & $\begin{array}{l}0.456^{\star} \\
{[0.231]}\end{array}$ & $\begin{array}{l}0.566^{\star} \\
{[0.309]}\end{array}$ & $\begin{array}{c}0.327^{\star *} \\
{[0.164]}\end{array}$ & $\begin{array}{l}0.096 \\
{[0.302]}\end{array}$ \\
\hline Year t-1 & $\begin{array}{c}0.467^{\star *} \\
{[0.191]}\end{array}$ & $\begin{array}{l}0.509^{\star} \\
{[0.269]}\end{array}$ & $\begin{array}{l}0.245 \\
{[0.172]}\end{array}$ & $\begin{array}{l}0.097 \\
{[0.257]}\end{array}$ \\
\hline Year Event & $\begin{array}{l}0.362^{*} \\
{[0.211]}\end{array}$ & $\begin{array}{c}0.793^{\star \star \star} \\
{[0.261]}\end{array}$ & $\begin{array}{c}1.001^{\star * \star} \\
{[0.213]}\end{array}$ & $\begin{array}{l}0.346 \\
{[0.249]}\end{array}$ \\
\hline Year $t+1$ & $\begin{array}{l}0.310^{\star} \\
{[0.175]}\end{array}$ & $\begin{array}{c}1.402^{\star \star \star} \\
{[0.318]}\end{array}$ & $\begin{array}{c}0.675^{\star \star \star} \\
{[0.197]}\end{array}$ & $\begin{array}{c}0.580^{* *} \\
{[0.249]}\end{array}$ \\
\hline Year $\mathbf{t}+2$ & $\begin{array}{l}0.290 \\
{[0.194]}\end{array}$ & $\begin{array}{c}1.199^{\star \star \star} \\
{[0.247]}\end{array}$ & $\begin{array}{l}0.332^{*} \\
{[0.168]}\end{array}$ & $\begin{array}{l}0.601^{*} \\
{[0.318]}\end{array}$ \\
\hline Year $\mathbf{t + 3}$ & $\begin{array}{l}0.187 \\
{[0.190]}\end{array}$ & $\begin{array}{l}0.983^{\star \star \star} \\
{[0.295]}\end{array}$ & $\begin{array}{l}0.077 \\
{[0.157]}\end{array}$ & $\begin{array}{l}0.383 \\
{[0.346]}\end{array}$ \\
\hline Observations & 1523 & 1523 & 1523 & 1523 \\
\hline R-squared & 0.08 & 0.08 & 0.08 & 0.08 \\
\hline No. of Countries & 73 & 73 & 73 & 73 \\
\hline No. of Events & 38 & 9 & 42 & 14 \\
\hline Country dummies & Yes & Yes & Yes & Yes \\
\hline Country trends & No & No & No & No \\
\hline
\end{tabular}

The table reports the coefficients obtained from a fixed-effects panel regression of the variable in the title on a seven-year window around crisis events, controlling for country fixed effects. Crisis events are spilt into independent debt crises; independent bank crises; twin debt-bank crises; and twin bank-debt crises. The variable is first normalized by dividing by the standard deviation at the country level. The sample period is 1975 to 2007 . Standard errors, clustered at the 


\section{Table 9. Claims on Government (\% GDP)}

\begin{tabular}{|c|c|c|c|c|}
\hline & D crises & DB crises & B crises & BD crises \\
\hline Year t-3 & $\begin{array}{c}-0.058 \\
{[0.164]}\end{array}$ & $\begin{array}{c}-0.345 \\
{[0.279]}\end{array}$ & $\begin{array}{c}-0.443^{\star \star \star} \\
{[0.159]}\end{array}$ & $\begin{array}{c}-0.701^{\star \star \star} \\
{[0.156]}\end{array}$ \\
\hline Year t-2 & $\begin{array}{l}0.051 \\
{[0.194]}\end{array}$ & $\begin{array}{l}-0.036 \\
{[0.278]}\end{array}$ & $\begin{array}{c}-0.203 \\
{[0.193]}\end{array}$ & $\begin{array}{c}-0.744^{\star \star \star} \\
{[0.223]}\end{array}$ \\
\hline Year t-1 & $\begin{array}{l}0.199 \\
{[0.212]}\end{array}$ & $\begin{array}{l}0.274 \\
{[0.281]}\end{array}$ & $\begin{array}{c}-0.370^{*} \\
{[0.192]}\end{array}$ & $\begin{array}{c}-0.464^{\star} \\
{[0.257]}\end{array}$ \\
\hline Year Event & $\begin{array}{l}0.064 \\
{[0.171]}\end{array}$ & $\begin{array}{l}0.175 \\
{[0.361]}\end{array}$ & $\begin{array}{c}-0.381^{\star \star} \\
{[0.167]}\end{array}$ & $\begin{array}{c}-0.085 \\
{[0.352]}\end{array}$ \\
\hline Year $t+1$ & $\begin{array}{l}0.023 \\
{[0.182]}\end{array}$ & $\begin{array}{l}0.106 \\
{[0.334]}\end{array}$ & $\begin{array}{r}-0.197 \\
{[0.137]}\end{array}$ & $\begin{array}{l}0.117 \\
{[0.341]}\end{array}$ \\
\hline Year $t+2$ & $\begin{array}{l}0.011 \\
{[0.209]}\end{array}$ & $\begin{array}{c}-0.002 \\
{[0.273]}\end{array}$ & $\begin{array}{c}-0.015 \\
{[0.135]}\end{array}$ & $\begin{array}{c}-0.012 \\
{[0.353]}\end{array}$ \\
\hline Year $t+3$ & $\begin{array}{c}-0.005 \\
{[0.200]}\end{array}$ & $\begin{array}{l}0.018 \\
{[0.224]}\end{array}$ & $\begin{array}{l}0.205 \\
{[0.150]}\end{array}$ & $\begin{array}{l}0.650 \\
{[0.453]}\end{array}$ \\
\hline Observations & 1716 & 1716 & 1716 & 1716 \\
\hline R-squared & 0.03 & 0.03 & 0.03 & 0.03 \\
\hline No. of Countries & 78 & 78 & 78 & 78 \\
\hline No. of Events & 44 & 12 & 45 & 14 \\
\hline Country dummies & Yes & Yes & Yes & Yes \\
\hline Country trends & No & No & No & No \\
\hline
\end{tabular}

The table reports the coefficients obtained from a fixed-effects panel regression of the variable in the title on a seven-year window around crisis events, controlling for country fixed effects. Crisis events are spilt into independent debt crises; independent bank crises; twin debt-bank crises; and twin bank-debt crises. The variable is first normalized by dividing by the standard deviation at the country level. The sample period is 1975 to 2007 . Standard errors, clustered at the country-level, are reported in brackets. ${ }^{*},{ }^{\star *}$, and ${ }^{* \star}$ mean significant at $10 \%, 5 \%$, and $1 \%$ respectively
Table 10. Claims on Government (\% total assets)

\begin{tabular}{|c|c|c|c|c|}
\hline & D crises & DB crises & B crises & BD crises \\
\hline Year t-3 & $\begin{array}{c}-0.075 \\
{[0.167]}\end{array}$ & $\begin{array}{c}-0.139 \\
{[0.336]}\end{array}$ & $\begin{array}{c}-0.252 \\
{[0.174]}\end{array}$ & $\begin{array}{c}-0.578^{\star \star \star} \\
{[0.176]}\end{array}$ \\
\hline Year t-2 & $\begin{array}{c}-0.043 \\
{[0.191]}\end{array}$ & $\begin{array}{l}0.205 \\
{[0.411]}\end{array}$ & $\begin{array}{c}-0.134 \\
{[0.199]}\end{array}$ & $\begin{array}{c}-0.529^{\star \star} \\
{[0.236]}\end{array}$ \\
\hline Year t-1 & $\begin{array}{l}0.151 \\
{[0.199]}\end{array}$ & $\begin{array}{l}0.360 \\
{[0.381]}\end{array}$ & $\begin{array}{c}-0.403^{\star \star} \\
{[0.181]}\end{array}$ & $\begin{array}{l}-0.315 \\
{[0.228]}\end{array}$ \\
\hline Year Event & $\begin{array}{l}0.008 \\
{[0.158]}\end{array}$ & $\begin{array}{l}0.142 \\
{[0.333]}\end{array}$ & $\begin{array}{l}-0.248 \\
{[0.186]}\end{array}$ & $\begin{array}{l}-0.134 \\
{[0.321]}\end{array}$ \\
\hline Year $t+1$ & $\begin{array}{l}0.012 \\
{[0.184]}\end{array}$ & $\begin{array}{l}0.314 \\
{[0.384]}\end{array}$ & $\begin{array}{l}0.040 \\
{[0.160]}\end{array}$ & $\begin{array}{l}0.055 \\
{[0.359]}\end{array}$ \\
\hline Year $t+2$ & $\begin{array}{c}-0.122 \\
{[0.190]}\end{array}$ & $\begin{array}{l}0.154 \\
{[0.328]}\end{array}$ & $\begin{array}{l}0.238 \\
{[0.143]}\end{array}$ & $\begin{array}{l}0.039 \\
{[0.306]}\end{array}$ \\
\hline Year $t+3$ & $\begin{array}{l}-0.096 \\
{[0.187]}\end{array}$ & $\begin{array}{l}0.216 \\
{[0.304]}\end{array}$ & $\begin{array}{c}0.368^{* *} \\
{[0.149]}\end{array}$ & $\begin{array}{l}0.636 \\
{[0.410]}\end{array}$ \\
\hline Observations & 1737 & 1737 & 1737 & 1737 \\
\hline R-squared & 0.03 & 0.03 & 0.03 & 0.03 \\
\hline No. of Countries & 78 & 78 & 78 & 78 \\
\hline No. of Events & 44 & 12 & 45 & 14 \\
\hline Country dummies & Yes & Yes & Yes & Yes \\
\hline Country trends & No & No & No & No \\
\hline
\end{tabular}

The table reports the coefficients obtained from a fixed-effects panel regression of the variable in the title on a seven-year window around crisis events, controlling for country fixed effects. Crisis events are spilt into independent debt crises; independent bank crises; twin debt-bank crises; and twin bank-debt spilt into independent debt crises; independent bank crises; twin debt-bank crises; and twin bank-debt
crises. The variable is first normalized by dividing by the standard deviation at the country level. The crises. The variable is first normalized by dividing by the standard deviation at the country level. The
sample period is 1975 to 2007 . Standard errors, clustered at the country-level, are reported in brackets. ${ }^{\star},{ }^{\star \star}$, and ${ }^{* \star}$ mean significant at $10 \%, 5 \%$, and $1 \%$ respectively 
Table 11. Assets (\% GDP)

\begin{tabular}{|c|c|c|c|c|}
\hline & D crises & DB crises & B crises & BD crises \\
\hline Year t-3 & $\begin{array}{l}0.091 \\
{[0.153]}\end{array}$ & $\begin{array}{l}-0.303 \\
{[0.247]}\end{array}$ & $\begin{array}{c}-0.323^{\star \star} \\
{[0.139]}\end{array}$ & $\begin{array}{l}0.322 \\
{[0.237]}\end{array}$ \\
\hline Year t-2 & $\begin{array}{l}0.244 \\
{[0.176]}\end{array}$ & $\begin{array}{l}-0.246 \\
{[0.245]}\end{array}$ & $\begin{array}{c}-0.166 \\
{[0.159]}\end{array}$ & $\begin{array}{l}0.284 \\
{[0.278]}\end{array}$ \\
\hline Year t-1 & $\begin{array}{l}0.191 \\
{[0.194]}\end{array}$ & $\begin{array}{l}0.105 \\
{[0.320]}\end{array}$ & $\begin{array}{l}0.231 \\
{[0.191]}\end{array}$ & $\begin{array}{l}0.432 \\
{[0.271]}\end{array}$ \\
\hline Year Event & $\begin{array}{l}0.404^{*} \\
{[0.242]}\end{array}$ & $\begin{array}{l}0.541 \\
{[0.388]}\end{array}$ & $\begin{array}{c}-0.023 \\
{[0.175]}\end{array}$ & $\begin{array}{c}0.710^{\star \star} \\
{[0.278]}\end{array}$ \\
\hline Year $t+1$ & $\begin{array}{l}0.247 \\
{[0.222]}\end{array}$ & $\begin{array}{c}-0.071 \\
{[0.220]}\end{array}$ & $\begin{array}{l}-0.227 \\
{[0.169]}\end{array}$ & $\begin{array}{c}0.821^{\star \star \star} \\
{[0.239]}\end{array}$ \\
\hline Year $t+2$ & $\begin{array}{l}0.170 \\
{[0.166]}\end{array}$ & $\begin{array}{l}-0.055 \\
{[0.208]}\end{array}$ & $\begin{array}{c}-0.297^{\star \star} \\
{[0.136]}\end{array}$ & $\begin{array}{l}0.538^{\star} \\
{[0.278]}\end{array}$ \\
\hline Year $t+3$ & $\begin{array}{l}0.094 \\
{[0.141]}\end{array}$ & $\begin{array}{c}-0.032 \\
{[0.256]}\end{array}$ & $\begin{array}{c}-0.195 \\
{[0.141]}\end{array}$ & $\begin{array}{c}0.553^{\star \star} \\
{[0.234]}\end{array}$ \\
\hline Observations & 1720 & 1720 & 1720 & 1720 \\
\hline R-squared & 0.47 & 0.47 & 0.47 & 0.47 \\
\hline No. of Countries & 78 & 78 & 78 & 78 \\
\hline No. of Events & 43 & 12 & 45 & 14 \\
\hline Country dummies & Yes & Yes & Yes & Yes \\
\hline Country trends & Yes & Yes & Yes & Yes \\
\hline
\end{tabular}

Table 12. Credit to the private sector (\% GDP)

\begin{tabular}{|c|c|c|c|c|}
\hline & D crises & DB crises & B crises & BD crises \\
\hline Year t-3 & $\begin{array}{c}0.273^{\star *} \\
{[0.130]}\end{array}$ & $\begin{array}{c}-0.084 \\
{[0.150]}\end{array}$ & $\begin{array}{c}-0.084 \\
{[0.146]}\end{array}$ & $\begin{array}{c}0.590^{\star *} \\
{[0.224]}\end{array}$ \\
\hline Year t-2 & $\begin{array}{c}0.358^{\star \star} \\
{[0.153]}\end{array}$ & $\begin{array}{c}-0.053 \\
{[0.212]}\end{array}$ & $\begin{array}{l}0.071 \\
{[0.180]}\end{array}$ & $\begin{array}{c}0.638^{\star \star} \\
{[0.265]}\end{array}$ \\
\hline Year t-1 & $\begin{array}{l}0.224 \\
{[0.171]}\end{array}$ & $\begin{array}{l}0.141 \\
{[0.214]}\end{array}$ & $\begin{array}{l}0.235 \\
{[0.188]}\end{array}$ & $\begin{array}{c}0.785^{\star \star \star} \\
{[0.282]}\end{array}$ \\
\hline Year Event & $\begin{array}{l}0.314 \\
{[0.218]}\end{array}$ & $\begin{array}{l}0.189 \\
{[0.299]}\end{array}$ & $\begin{array}{l}0.209 \\
{[0.204]}\end{array}$ & $\begin{array}{c}0.827^{\star \star \star} \\
{[0.309]}\end{array}$ \\
\hline Year $t+1$ & $\begin{array}{l}0.101 \\
{[0.178]}\end{array}$ & $\begin{array}{c}-0.178 \\
{[0.183]}\end{array}$ & $\begin{array}{l}-0.132 \\
{[0.182]}\end{array}$ & $\begin{array}{c}0.710^{* *} \\
{[0.292]}\end{array}$ \\
\hline Year $t+2$ & $\begin{array}{l}0.116 \\
{[0.138]}\end{array}$ & $\begin{array}{c}-0.282 \\
{[0.208]}\end{array}$ & $\begin{array}{l}-0.161 \\
{[0.148]}\end{array}$ & $\begin{array}{l}0.298 \\
{[0.347]}\end{array}$ \\
\hline Year $t+3$ & $\begin{array}{l}0.065 \\
{[0.129]}\end{array}$ & $\begin{array}{l}-0.236 \\
{[0.249]}\end{array}$ & $\begin{array}{l}-0.111 \\
{[0.133]}\end{array}$ & $\begin{array}{l}0.264 \\
{[0.288]}\end{array}$ \\
\hline Observations & 1786 & 1786 & 1786 & 1786 \\
\hline R-squared & 0.49 & 0.49 & 0.49 & 0.49 \\
\hline No. of Countries & 78 & 78 & 78 & 78 \\
\hline No. of Events & 48 & 13 & 47 & 15 \\
\hline Country dummies & Yes & Yes & Yes & Yes \\
\hline Country trends & Yes & Yes & Yes & Yes \\
\hline
\end{tabular}

The table reports the coefficients obtained from a fixed-effects panel regression of the variable in the title on a seven-year window around crisis events, controlling for country fixed effects. Crisis events are spit into independ is crises. The varable is first crom sample period is 1975 to 2007 . Standard errors, clustered at the country-level, are reported in brackets.
${ }^{\star *}$, and ${ }^{\star \star *}$ mean significant at $10 \%, 5 \%$, and $1 \%$ respectively 
Table 13. Deposits (\% GDP)

\begin{tabular}{|c|c|c|c|c|}
\hline & D crises & DB crises & B crises & BD crises \\
\hline Year t-3 & $\begin{array}{l}-0.001 \\
{[0.157]}\end{array}$ & $\begin{array}{l}0.094 \\
{[0.227]}\end{array}$ & $\begin{array}{c}-0.084 \\
{[0.144]}\end{array}$ & $\begin{array}{c}0.582^{\star \star} \\
{[0.258]}\end{array}$ \\
\hline Year t-2 & $\begin{array}{l}0.080 \\
{[0.178]}\end{array}$ & $\begin{array}{l}0.189 \\
{[0.294]}\end{array}$ & $\begin{array}{l}-0.031 \\
{[0.179]}\end{array}$ & $\begin{array}{l}0.348 \\
{[0.270]}\end{array}$ \\
\hline Year t-1 & $\begin{array}{l}0.106 \\
{[0.204]}\end{array}$ & $\begin{array}{l}0.496 \\
{[0.367]}\end{array}$ & $\begin{array}{l}0.221 \\
{[0.169]}\end{array}$ & $\begin{array}{l}0.367^{*} \\
{[0.196]}\end{array}$ \\
\hline Year Event & $\begin{array}{l}0.134 \\
{[0.242]}\end{array}$ & $\begin{array}{l}0.143 \\
{[0.319]}\end{array}$ & $\begin{array}{l}-0.023 \\
{[0.183]}\end{array}$ & $\begin{array}{c}0.718^{\star \star \star} \\
{[0.230]}\end{array}$ \\
\hline Year $t+1$ & $\begin{array}{l}0.018 \\
{[0.227]}\end{array}$ & $\begin{array}{c}-0.196 \\
{[0.277]}\end{array}$ & $\begin{array}{c}-0.249 \\
{[0.168]}\end{array}$ & $\begin{array}{l}0.217 \\
{[0.271]}\end{array}$ \\
\hline Year $t+2$ & $\begin{array}{l}0.025 \\
{[0.169]}\end{array}$ & $\begin{array}{l}-0.147 \\
{[0.292]}\end{array}$ & $\begin{array}{c}-0.260^{\star} \\
{[0.137]}\end{array}$ & $\begin{array}{l}0.216 \\
{[0.178]}\end{array}$ \\
\hline Year $t+3$ & $\begin{array}{l}0.004 \\
{[0.139]}\end{array}$ & $\begin{array}{l}-0.092 \\
{[0.259]}\end{array}$ & $\begin{array}{c}-0.333^{\star *} \\
{[0.139]}\end{array}$ & $\begin{array}{l}0.263 \\
{[0.159]}\end{array}$ \\
\hline Observations & 1801 & 1801 & 1801 & 1801 \\
\hline R-squared & 0.45 & 0.45 & 0.45 & 0.45 \\
\hline No. of Countries & 78 & 78 & 78 & 78 \\
\hline No. of Events & 48 & 13 & 49 & 15 \\
\hline Country dummies & Yes & Yes & Yes & Yes \\
\hline Country trends & Yes & Yes & Yes & Yes \\
\hline
\end{tabular}

The table reports the coefficients obtained from a fixed-effects panel regression of the variable in the title on a seven-year window around crisis events, controlling for country fixed effects. Crisis events are spilt into independent debt crises; independent bank crises; twin debt-bank crises; and twin bank-debt crises. The variable is first normalized by dividing by the standard deviation at the country level. The sample period is 1975 to 2007 . Standard errors, clustered at the country-level, are reported in brackets. ${ }^{\star},{ }^{\star \star}$, and ${ }^{* \star \star}$ mean significant at $10 \%, 5 \%$, and $1 \%$ respectively
Table 14. Budget Balance (\% GDP)

\begin{tabular}{|c|c|c|c|c|}
\hline & D crises & DB crises & B crises & BD crises \\
\hline Year t-3 & $\begin{array}{c}-0.566^{\star \star \star} \\
{[0.198]}\end{array}$ & $\begin{array}{l}-0.385 \\
{[0.336]}\end{array}$ & $\begin{array}{l}0.323^{\star} \\
{[0.184]}\end{array}$ & $\begin{array}{l}0.139 \\
{[0.293]}\end{array}$ \\
\hline Year t-2 & $\begin{array}{c}-0.428^{\star \star} \\
{[0.206]}\end{array}$ & $\begin{array}{l}0.225 \\
{[0.329]}\end{array}$ & $\begin{array}{l}0.099 \\
{[0.215]}\end{array}$ & $\begin{array}{l}-0.126 \\
{[0.345]}\end{array}$ \\
\hline Year t-1 & $\begin{array}{c}-0.558^{\star \star \star} \\
{[0.197]}\end{array}$ & $\begin{array}{l}-0.264 \\
{[0.517]}\end{array}$ & $\begin{array}{l}-0.093 \\
{[0.202]}\end{array}$ & $\begin{array}{l}-0.163 \\
{[0.348]}\end{array}$ \\
\hline Year Event & $\begin{array}{c}-0.218 \\
{[0.193]}\end{array}$ & $\begin{array}{c}-0.132 \\
{[0.286]}\end{array}$ & $\begin{array}{l}-0.219 \\
{[0.161]}\end{array}$ & $\begin{array}{l}-0.401 \\
{[0.354]}\end{array}$ \\
\hline Year $t+1$ & $\begin{array}{c}-0.240 \\
{[0.249]}\end{array}$ & $\begin{array}{c}0.389^{\star *} \\
{[0.186]}\end{array}$ & $\begin{array}{c}-0.358^{\star \star} \\
{[0.153]}\end{array}$ & $\begin{array}{c}-1.036^{\star \star \star} \\
{[0.347]}\end{array}$ \\
\hline Year $\mathbf{t + 2}$ & $\begin{array}{l}-0.298 \\
{[0.232]}\end{array}$ & $\begin{array}{l}0.119 \\
{[0.226]}\end{array}$ & $\begin{array}{c}-0.377^{\star \star} \\
{[0.158]}\end{array}$ & $\begin{array}{c}-0.533 \\
{[0.337]}\end{array}$ \\
\hline Year $\mathbf{t + 3}$ & $\begin{array}{l}-0.135 \\
{[0.237]}\end{array}$ & $\begin{array}{l}0.365 \\
{[0.324]}\end{array}$ & $\begin{array}{l}-0.059 \\
{[0.153]}\end{array}$ & $\begin{array}{l}-0.400 \\
{[0.313]}\end{array}$ \\
\hline Observations & 1548 & 1548 & 1548 & 1548 \\
\hline R-squared & 0.05 & 0.05 & 0.05 & 0.05 \\
\hline No. of Countries & 76 & 76 & 76 & 76 \\
\hline No. of Events & 41 & 11 & 41 & 13 \\
\hline Country dummies & Yes & Yes & Yes & Yes \\
\hline Country trends & No & No & No & No \\
\hline
\end{tabular}

The table reports the coefficients obtained from a fixed-effects panel regression of the variable in the title on a seven-year window around crisis events, controlling for country fixed effects. Crisis events are spilt into independent debt crises; independent bank crises; twin debt-bank crises; and twin bank-debt crises. The variable is first normalized by dividing by the standard deviation at the country level. The sample period is 1975 to 2007 . Standard errors, clustered at the country-level, are reported in brackets. ${ }^{*}$,*, and ${ }^{* \star *}$ mean significant at $10 \%, 5 \%$, and $1 \%$ respectively 


\section{Table 15. Budget Expense (\% GDP)}

\begin{tabular}{|c|c|c|c|c|}
\hline & D crises & DB crises & B crises & BD crises \\
\hline Year t-3 & $\begin{array}{c}0.480^{\star \star} \\
{[0.206]}\end{array}$ & $\begin{array}{l}0.513 \\
{[0.328]}\end{array}$ & $\begin{array}{c}-0.158 \\
{[0.190]}\end{array}$ & $\begin{array}{l}-0.028 \\
{[0.324]}\end{array}$ \\
\hline Year t-2 & $\begin{array}{c}0.423^{\star \star} \\
{[0.197]}\end{array}$ & $\begin{array}{l}0.622^{*} \\
{[0.337]}\end{array}$ & $\begin{array}{l}0.084 \\
{[0.199]}\end{array}$ & $\begin{array}{l}0.063 \\
{[0.334]}\end{array}$ \\
\hline Year t-1 & $\begin{array}{c}0.509^{\star *} \\
{[0.223]}\end{array}$ & $\begin{array}{l}0.627^{\star} \\
{[0.355]}\end{array}$ & $\begin{array}{l}0.186 \\
{[0.194]}\end{array}$ & $\begin{array}{l}0.009 \\
{[0.368]}\end{array}$ \\
\hline Year Event & $\begin{array}{c}0.448^{\star \star} \\
{[0.211]}\end{array}$ & $\begin{array}{l}0.279 \\
{[0.345]}\end{array}$ & $\begin{array}{l}0.187 \\
{[0.210]}\end{array}$ & $\begin{array}{c}-0.096 \\
{[0.350]}\end{array}$ \\
\hline Year $t+1$ & $\begin{array}{l}0.321 \\
{[0.216]}\end{array}$ & $\begin{array}{c}-0.560^{*} \\
{[0.333]}\end{array}$ & $\begin{array}{l}0.235 \\
{[0.190]}\end{array}$ & $\begin{array}{l}0.385 \\
{[0.444]}\end{array}$ \\
\hline Year $t+2$ & $\begin{array}{l}0.205 \\
{[0.162]}\end{array}$ & $\begin{array}{c}-0.478^{*} \\
{[0.266]}\end{array}$ & $\begin{array}{l}0.267 \\
{[0.173]}\end{array}$ & $\begin{array}{l}0.272 \\
{[0.441]}\end{array}$ \\
\hline Year $t+3$ & $\begin{array}{l}0.125 \\
{[0.183]}\end{array}$ & $\begin{array}{l}-0.300 \\
{[0.349]}\end{array}$ & $\begin{array}{l}0.135 \\
{[0.156]}\end{array}$ & $\begin{array}{l}0.099 \\
{[0.362]}\end{array}$ \\
\hline Observations & 1548 & 1548 & 1548 & 1548 \\
\hline R-squared & 0.04 & 0.04 & 0.04 & 0.04 \\
\hline No. of Countries & 76 & 76 & 76 & 76 \\
\hline No. of Events & 41 & 11 & 42 & 13 \\
\hline Country dummies & Yes & Yes & Yes & Yes \\
\hline Country trends & No & No & No & No \\
\hline
\end{tabular}

The table reports the coefficients obtained from a fixed-effects panel regression of the variable in the title on a seven-year window around crisis events, controlling for country fixed effects. Crisis events are spilt into independent debt crises; independent bank crises; twin debt-bank crises; and twin bank-debt crises. The variable is first normalized by dividing by the standard deviation at the country level. The sample period is 1975 to 2007 . Standard errors, clustered at the country-level, are reported in brackets. ${ }^{*},{ }^{\star *}$, and ${ }^{* \star}$ mean significant at $10 \%, 5 \%$, and $1 \%$ respectively

\section{Table 16. Budget Revenue (\% GDP)}

\begin{tabular}{|c|c|c|c|c|}
\hline & D crises & DB crises & B crises & BD crises \\
\hline Year t-3 & $\begin{array}{l}0.128 \\
{[0.174]}\end{array}$ & $\begin{array}{l}0.404 \\
{[0.433]}\end{array}$ & $\begin{array}{l}0.037 \\
{[0.228]}\end{array}$ & $\begin{array}{c}-0.156 \\
{[0.279]}\end{array}$ \\
\hline Year t-2 & $\begin{array}{l}0.115 \\
{[0.203]}\end{array}$ & $\begin{array}{l}0.582 \\
{[0.488]}\end{array}$ & $\begin{array}{l}0.226 \\
{[0.183]}\end{array}$ & $\begin{array}{c}-0.307 \\
{[0.313]}\end{array}$ \\
\hline Year t-1 & $\begin{array}{l}0.034 \\
{[0.187]}\end{array}$ & $\begin{array}{l}0.106 \\
{[0.477]}\end{array}$ & $\begin{array}{l}0.100 \\
{[0.166]}\end{array}$ & $\begin{array}{c}-0.169 \\
{[0.352]}\end{array}$ \\
\hline Year Event & $\begin{array}{l}0.317 \\
{[0.214]}\end{array}$ & $\begin{array}{l}0.236 \\
{[0.433]}\end{array}$ & $\begin{array}{c}-0.164 \\
{[0.193]}\end{array}$ & $\begin{array}{c}-0.411 \\
{[0.316]}\end{array}$ \\
\hline Year $t+1$ & $\begin{array}{l}0.117 \\
{[0.194]}\end{array}$ & $\begin{array}{c}-0.078 \\
{[0.415]}\end{array}$ & $\begin{array}{c}-0.033 \\
{[0.181]}\end{array}$ & $\begin{array}{c}-0.374 \\
{[0.306]}\end{array}$ \\
\hline Year $t+2$ & $\begin{array}{c}-0.014 \\
{[0.197]}\end{array}$ & $\begin{array}{l}-0.347 \\
{[0.378]}\end{array}$ & $\begin{array}{l}0.000 \\
{[0.161]}\end{array}$ & $\begin{array}{c}-0.149 \\
{[0.309]}\end{array}$ \\
\hline Year $\mathbf{t + 3}$ & $\begin{array}{l}0.024 \\
{[0.200]}\end{array}$ & $\begin{array}{l}0.141 \\
{[0.391]}\end{array}$ & $\begin{array}{l}0.132 \\
{[0.161]}\end{array}$ & $\begin{array}{c}-0.354 \\
{[0.384]}\end{array}$ \\
\hline Observations & 1564 & 1564 & 1564 & 1564 \\
\hline R-squared & 0.02 & 0.02 & 0.02 & 0.02 \\
\hline No. of Countries & 76 & 76 & 76 & 76 \\
\hline No. of Events & 41 & 11 & 42 & 13 \\
\hline Country dummies & Yes & Yes & Yes & Yes \\
\hline Country trends & No & No & No & No \\
\hline
\end{tabular}

The table reports the coefficients obtained from a fixed-effects panel regression of the variable in the title on a seven-year window around crisis events, controlling for country fixed effects. Crisis events are spilt into independent debt crises; independent bank crises; twin debt-bank crises; and twin bank-debt spilt into independent debt crises, independent bank crises, twin debt-bank crises, and twin bank-debt crises. The variable is first normalized by dividing by the standard deviation at the country level. The sample period is 1975 to 2007 . Standard errors, clustered at the country-level, are reported in brackets. ${ }^{*},{ }^{\star}$, and ${ }^{* \star *}$ mean significant at $10 \%, 5 \%$, and $1 \%$ respectively 


\section{Table 17. Government Debt (\% GDP)}

\begin{tabular}{|c|c|c|c|c|}
\hline & D crises & DB crises & B crises & BD crises \\
\hline Year t-3 & $\begin{array}{c}-0.324 \\
{[0.209]}\end{array}$ & $\begin{array}{l}0.021 \\
{[0.368]}\end{array}$ & $\begin{array}{c}-0.207 \\
{[0.182]}\end{array}$ & $\begin{array}{c}-0.433^{\star} \\
{[0.259]}\end{array}$ \\
\hline Year t-2 & $\begin{array}{l}-0.128 \\
{[0.230]}\end{array}$ & $\begin{array}{l}0.331 \\
{[0.400]}\end{array}$ & $\begin{array}{c}-0.094 \\
{[0.175]}\end{array}$ & $\begin{array}{c}-0.567^{\star \star} \\
{[0.243]}\end{array}$ \\
\hline Year t-1 & $\begin{array}{l}-0.058 \\
{[0.249]}\end{array}$ & $\begin{array}{l}0.665 \\
{[0.523]}\end{array}$ & $\begin{array}{l}0.026 \\
{[0.213]}\end{array}$ & $\begin{array}{c}-0.592^{\star \star} \\
{[0.238]}\end{array}$ \\
\hline Year Event & $\begin{array}{l}0.095 \\
{[0.214]}\end{array}$ & $\begin{array}{l}0.624 \\
{[0.429]}\end{array}$ & $\begin{array}{l}-0.015 \\
{[0.203]}\end{array}$ & $\begin{array}{l}-0.120 \\
{[0.285]}\end{array}$ \\
\hline Year $t+1$ & $\begin{array}{c}0.453^{\star \star} \\
{[0.195]}\end{array}$ & $\begin{array}{c}1.010^{\star \star} \\
{[0.493]}\end{array}$ & $\begin{array}{l}0.010 \\
{[0.168]}\end{array}$ & $\begin{array}{l}0.248 \\
{[0.230]}\end{array}$ \\
\hline Year $t+2$ & $\begin{array}{l}0.239 \\
{[0.161]}\end{array}$ & $\begin{array}{l}0.852^{*} \\
{[0.444]}\end{array}$ & $\begin{array}{l}0.120 \\
{[0.171]}\end{array}$ & $\begin{array}{c}0.658^{\star \star} \\
{[0.305]}\end{array}$ \\
\hline Year $t+3$ & $\begin{array}{c}0.441^{\star *} \\
{[0.168]}\end{array}$ & $\begin{array}{l}0.544 \\
{[0.392]}\end{array}$ & $\begin{array}{l}0.191 \\
{[0.160]}\end{array}$ & $\begin{array}{c}0.870^{\star \star \star} \\
{[0.325]}\end{array}$ \\
\hline Observations & 1639 & 1639 & 1639 & 1639 \\
\hline R-squared & 0.05 & 0.05 & 0.05 & 0.05 \\
\hline No. of Countries & 73 & 73 & 73 & 73 \\
\hline No. of Events & 44 & 9 & 43 & 14 \\
\hline Country dummies & Yes & Yes & Yes & Yes \\
\hline Country trends & No & No & No & No \\
\hline
\end{tabular}

The table reports the coefficients obtained from a fixed-effects panel regression of the variable in the title on a seven-year window around crisis events, controlling for country fixed effects. Crisis events are spilt into independent debt crises; independent bank crises; twin debt-bank crises; and twin bank-debt crises. The variable is first normalized by dividing by the standard deviation at the country level. The sample period is 1975 to 2007 . Standard errors, clustered at the country-level, are reported in brackets. ${ }^{\star},{ }^{* *}$, and ${ }^{* \star *}$ mean significant at $10 \%, 5 \%$, and $1 \%$ respectively
Table 18. Real GDP growth (\%)

\begin{tabular}{|c|c|c|c|c|}
\hline & D crises & DB crises & B crises & BD crises \\
\hline Year t-3 & $\begin{array}{c}-0.353^{*} \\
{[0.189]}\end{array}$ & $\begin{array}{c}-0.289 \\
{[0.266]}\end{array}$ & $\begin{array}{c}-0.222 \\
{[0.184]}\end{array}$ & $\begin{array}{l}0.238 \\
{[0.274]}\end{array}$ \\
\hline Year t-2 & $\begin{array}{c}-0.198 \\
{[0.171]}\end{array}$ & $\begin{array}{c}-0.527^{\star \star \star} \\
{[0.163]}\end{array}$ & $\begin{array}{c}-0.341^{\star \star} \\
{[0.157]}\end{array}$ & $\begin{array}{l}0.030 \\
{[0.230]}\end{array}$ \\
\hline Year t-1 & $\begin{array}{c}-0.535^{\star \star \star} \\
{[0.196]}\end{array}$ & $\begin{array}{c}-0.347 \\
{[0.217]}\end{array}$ & $\begin{array}{c}-0.303 \\
{[0.200]}\end{array}$ & $\begin{array}{l}0.230 \\
{[0.181]}\end{array}$ \\
\hline Year Event & $\begin{array}{c}-0.558^{\star \star \star} \\
{[0.172]}\end{array}$ & $\begin{array}{c}-1.262^{\star \star \star} \\
{[0.290]}\end{array}$ & $\begin{array}{c}-0.374^{\star \star} \\
{[0.183]}\end{array}$ & $\begin{array}{c}-0.641^{\star \star} \\
{[0.253]}\end{array}$ \\
\hline Year $t+1$ & $\begin{array}{c}-0.350^{\star \star} \\
{[0.145]}\end{array}$ & $\begin{array}{c}-0.928^{\star \star} \\
{[0.432]}\end{array}$ & $\begin{array}{c}-0.478^{\star \star} \\
{[0.222]}\end{array}$ & $\begin{array}{c}-1.722^{\star \star \star} \\
{[0.407]}\end{array}$ \\
\hline Year $\mathbf{t}+2$ & $\begin{array}{c}-0.262 \\
{[0.165]}\end{array}$ & $\begin{array}{c}-0.046 \\
{[0.338]}\end{array}$ & $\begin{array}{l}-0.051 \\
{[0.125]}\end{array}$ & $\begin{array}{c}-0.848^{* \star \star} \\
{[0.316]}\end{array}$ \\
\hline Year $t+3$ & $\begin{array}{c}-0.043 \\
{[0.186]}\end{array}$ & $\begin{array}{l}0.298 \\
{[0.383]}\end{array}$ & $\begin{array}{l}0.091 \\
{[0.105]}\end{array}$ & $\begin{array}{c}-0.298 \\
{[0.222]}\end{array}$ \\
\hline Observations & 1855 & 1855 & 1855 & 1855 \\
\hline R-squared & 0.07 & 0.07 & 0.07 & 0.07 \\
\hline No. of Countries & 76 & 76 & 76 & 76 \\
\hline No. of Events & 47 & 12 & 46 & 14 \\
\hline Country dummies & Yes & Yes & Yes & Yes \\
\hline Country trends & No & No & No & No \\
\hline
\end{tabular}

The table reports the coefficients obtained from a fixed-effects panel regression of the variable in the title on a seven-year window around crisis events, controlling for country fixed effects. Crisis events are title on a seven-yar window around crisis events, controlling for county fixed effects. Crisis events are spitt into independent debt crises, independent bank crises, twin debt-bank crises, and twin bank-debt crises. The variable is first normalized by dividing by the standard deviation at the country level. The sample period is 1975 to 2007 . Standard errors, clustered at the country-level, are reported in brackets. ${ }^{*},{ }^{\star}$, and ${ }^{* \star \star}$ mean significant at $10 \%, 5 \%$, and $1 \%$ respectively 


\section{Table 19. Inflation rate (\%)}

\begin{tabular}{|c|c|c|c|c|}
\hline & D crises & DB crises & B crises & BD crises \\
\hline Year t-3 & $\begin{array}{l}0.257 \\
{[0.198]}\end{array}$ & $\begin{array}{c}1.038^{\star \star} \\
{[0.479]}\end{array}$ & $\begin{array}{c}0.907^{\star \star \star} \\
{[0.253]}\end{array}$ & $\begin{array}{l}0.131 \\
{[0.263]}\end{array}$ \\
\hline Year t-2 & $\begin{array}{l}0.194 \\
{[0.163]}\end{array}$ & $\begin{array}{l}0.331 \\
{[0.324]}\end{array}$ & $\begin{array}{c}0.714^{\star \star \star} \\
{[0.198]}\end{array}$ & $\begin{array}{l}0.255 \\
{[0.232]}\end{array}$ \\
\hline Year t-1 & $\begin{array}{l}0.169 \\
{[0.119]}\end{array}$ & $\begin{array}{l}0.304 \\
{[0.341]}\end{array}$ & $\begin{array}{c}0.491^{\star \star \star} \\
{[0.179]}\end{array}$ & $\begin{array}{l}0.023 \\
{[0.184]}\end{array}$ \\
\hline Year Event & $\begin{array}{l}0.215 \\
{[0.165]}\end{array}$ & $\begin{array}{l}0.693 \\
{[0.556]}\end{array}$ & $\begin{array}{c}0.347^{\star \star} \\
{[0.171]}\end{array}$ & $\begin{array}{l}0.230 \\
{[0.229]}\end{array}$ \\
\hline Year $t+1$ & $\begin{array}{l}0.358 \\
{[0.223]}\end{array}$ & $\begin{array}{l}0.424 \\
{[0.320]}\end{array}$ & $\begin{array}{l}0.243 \\
{[0.155]}\end{array}$ & $\begin{array}{c}1.444^{\star \star \star} \\
{[0.517]}\end{array}$ \\
\hline Year $\mathbf{t + 2}$ & $\begin{array}{l}0.256^{\star} \\
{[0.130]}\end{array}$ & $\begin{array}{l}0.463 \\
{[0.315]}\end{array}$ & $\begin{array}{l}0.131 \\
{[0.170]}\end{array}$ & $\begin{array}{c}1.317^{\star \star \star} \\
{[0.389]}\end{array}$ \\
\hline Year $\mathbf{t + 3}$ & $\begin{array}{l}0.192 \\
{[0.160]}\end{array}$ & $\begin{array}{c}-0.259^{\star \star} \\
{[0.110]}\end{array}$ & $\begin{array}{c}-0.178 \\
{[0.119]}\end{array}$ & $\begin{array}{l}0.581^{*} \\
{[0.329]}\end{array}$ \\
\hline Observations & 1614 & 1614 & 1614 & 1614 \\
\hline R-squared & 0.08 & 0.08 & 0.08 & 0.08 \\
\hline No. of Countries & 72 & 72 & 72 & 72 \\
\hline No. of Events & 46 & 10 & 37 & 15 \\
\hline Country dummies & Yes & Yes & Yes & Yes \\
\hline Country trends & No & No & No & No \\
\hline
\end{tabular}

The table reports the coefficients obtained from a fixed-effects panel regression of the variable in the title on a seven-year window around crisis events, controlling for country fixed effects. Crisis events are spilt into independent debt crises; independent bank crises; twin debt-bank crises; and twin bank-debt crises. The variable is first normalized by dividing by the standard deviation at the country level. The sample period is 1975 to 2007. Standard errors, clustered at the country-level, are reported in brackets. ${ }^{*},{ }^{\star *}$, and ${ }^{* \star}$ mean significant at $10 \%, 5 \%$, and $1 \%$ respectively

\section{Table 20. Capital inflows (\% GDP)}

\begin{tabular}{|c|c|c|c|c|}
\hline & D crises & DB crises & B crises & BD crises \\
\hline Year t-3 & $\begin{array}{c}0.457^{\star \star} \\
{[0.180]}\end{array}$ & $\begin{array}{c}-0.628^{\star \star} \\
{[0.292]}\end{array}$ & $\begin{array}{l}0.127 \\
{[0.149]}\end{array}$ & $\begin{array}{l}0.152 \\
{[0.348]}\end{array}$ \\
\hline Year t-2 & $\begin{array}{l}0.238 \\
{[0.175]}\end{array}$ & $\begin{array}{l}-0.415 \\
{[0.253]}\end{array}$ & $\begin{array}{l}0.267 \\
{[0.186]}\end{array}$ & $\begin{array}{l}0.378 \\
{[0.273]}\end{array}$ \\
\hline Year t-1 & $\begin{array}{l}0.033 \\
{[0.166]}\end{array}$ & $\begin{array}{c}-0.364 \\
{[0.291]}\end{array}$ & $\begin{array}{c}0.376^{\star *} \\
{[0.187]}\end{array}$ & $\begin{array}{c}0.529^{\star *} \\
{[0.224]}\end{array}$ \\
\hline Year Event & $\begin{array}{l}-0.096 \\
{[0.223]}\end{array}$ & $\begin{array}{c}-0.919^{\star \star \star} \\
{[0.301]}\end{array}$ & $\begin{array}{l}0.143 \\
{[0.142]}\end{array}$ & $\begin{array}{l}-0.057 \\
{[0.450]}\end{array}$ \\
\hline Year $t+1$ & $\begin{array}{c}-0.268 \\
{[0.203]}\end{array}$ & $\begin{array}{c}-0.948^{\star \star \star} \\
{[0.329]}\end{array}$ & $\begin{array}{l}-0.081 \\
{[0.186]}\end{array}$ & $\begin{array}{c}-0.504 \\
{[0.367]}\end{array}$ \\
\hline Year $t+2$ & $\begin{array}{l}-0.306 \\
{[0.213]}\end{array}$ & $\begin{array}{l}-0.310 \\
{[0.507]}\end{array}$ & $\begin{array}{l}0.127 \\
{[0.190]}\end{array}$ & $\begin{array}{c}-1.024^{\star \star \star} \\
{[0.325]}\end{array}$ \\
\hline Year $\mathbf{t + 3}$ & $\begin{array}{c}-0.232 \\
{[0.144]}\end{array}$ & $\begin{array}{c}-0.352^{\star} \\
{[0.207]}\end{array}$ & $\begin{array}{l}0.012 \\
{[0.154]}\end{array}$ & $\begin{array}{c}-0.418^{\star \star \star} \\
{[0.156]}\end{array}$ \\
\hline Observations & 1603 & 1603 & 1603 & 1603 \\
\hline R-squared & 0.27 & 0.27 & 0.27 & 0.27 \\
\hline No. of Countries & 71 & 71 & 71 & 71 \\
\hline No. of Events & 46 & 11 & 40 & 15 \\
\hline Country dummies & Yes & Yes & Yes & Yes \\
\hline Country trends & Yes & Yes & Yes & Yes \\
\hline
\end{tabular}

The table reports the coefficients obtained from a fixed-effects panel regression of the variable in the title on a seven-year window around crisis events, controlling for country fixed effects. Crisis events are spilt into independent debt crises; independent bank crises; twin debt-bank crises; and twin bank-debt spilt into independent debt crises, independent bank crises, twin debt-bank crises, and twin bank-debt crises. The variable is first normalized by dividing by the standard deviation at the country level. The sample period is 1975 to 2007 . Standard errors, clustered at the country-level, are reported in brackets. ${ }^{*},{ }^{\star}$, and ${ }^{* \star \star}$ mean significant at $10 \%, 5 \%$, and $1 \%$ respectively 


\section{Table 21. Short-term debt (\% External debt)}

\begin{tabular}{|c|c|c|c|c|}
\hline & D crises & DB crises & B crises & BD crises \\
\hline Year t-3 & $\begin{array}{l}0.067 \\
{[0.165]}\end{array}$ & $\begin{array}{c}-0.084 \\
{[0.214]}\end{array}$ & $\begin{array}{c}-0.003 \\
{[0.172]}\end{array}$ & $\begin{array}{l}0.283 \\
{[0.243]}\end{array}$ \\
\hline Year t-2 & $\begin{array}{l}0.173 \\
{[0.198]}\end{array}$ & $\begin{array}{c}-0.195 \\
{[0.266]}\end{array}$ & $\begin{array}{l}-0.051 \\
{[0.173]}\end{array}$ & $\begin{array}{c}0.555^{\star \star} \\
{[0.236]}\end{array}$ \\
\hline Year t-1 & $\begin{array}{l}0.159 \\
{[0.195]}\end{array}$ & $\begin{array}{l}-0.069 \\
{[0.365]}\end{array}$ & $\begin{array}{l}0.182 \\
{[0.206]}\end{array}$ & $\begin{array}{c}0.950^{\star \star \star} \\
{[0.314]}\end{array}$ \\
\hline Year Event & $\begin{array}{l}-0.093 \\
{[0.185]}\end{array}$ & $\begin{array}{l}-0.035 \\
{[0.333]}\end{array}$ & $\begin{array}{l}0.161 \\
{[0.204]}\end{array}$ & $\begin{array}{l}0.582 \\
{[0.352]}\end{array}$ \\
\hline Year $t+1$ & $\begin{array}{c}-0.326^{\star \star} \\
{[0.140]}\end{array}$ & $\begin{array}{l}0.086 \\
{[0.355]}\end{array}$ & $\begin{array}{c}-0.016 \\
{[0.164]}\end{array}$ & $\begin{array}{l}0.157 \\
{[0.331]}\end{array}$ \\
\hline Year $\mathbf{t + 2}$ & $\begin{array}{c}-0.370^{\star * \star} \\
{[0.132]}\end{array}$ & $\begin{array}{l}0.220 \\
{[0.277]}\end{array}$ & $\begin{array}{c}-0.002 \\
{[0.211]}\end{array}$ & $\begin{array}{c}-0.119 \\
{[0.354]}\end{array}$ \\
\hline Year $\mathbf{t}+3$ & $\begin{array}{c}-0.309^{* *} \\
{[0.154]}\end{array}$ & $\begin{array}{l}0.438^{*} \\
{[0.252]}\end{array}$ & $\begin{array}{l}-0.133 \\
{[0.146]}\end{array}$ & $\begin{array}{c}-0.380^{\star} \\
{[0.214]}\end{array}$ \\
\hline Observations & 1602 & 1602 & 1602 & 1602 \\
\hline R-squared & 0.03 & 0.03 & 0.03 & 0.03 \\
\hline No. of Countries & 65 & 65 & 65 & 65 \\
\hline No. of Events & 48 & 12 & 40 & 15 \\
\hline Country dummies & Yes & Yes & Yes & Yes \\
\hline Country trends & No & No & No & No \\
\hline
\end{tabular}

The table reports the coefficients obtained from a fixed-effects panel regression of the variable in the title on a seven-year window around crisis events, controlling for country fixed effects. Crisis events are spilt into independent debt crises; independent bank crises; twin debt-bank crises; and twin bank-debt spilt into independent debt crises; independent bank crises; twin debt-bank crises; and twin bank-debt
crises. The variable is first normalized by dividing by the standard deviation at the country level. The sample period is 1975 to 2007 . Standard errors, clustered at the country-level, are reported in brackets. ${ }^{*},{ }^{\star *}$, and ${ }^{* \star *}$ mean significant at $10 \%, 5 \%$, and $1 \%$ respectively. 
